\title{
Qualitative and quantitative reconstructions of surface water characteristics and recent hydrographical changes in the Trondheimsfjord, central Norway
}

\author{
G. Milzer ${ }^{1}$, J. Giraudeau ${ }^{1}$, S. Schmidt ${ }^{1}$, F. Eynaud ${ }^{1}$, and J. Faust ${ }^{2}$ \\ ${ }^{1}$ Environnements et Paléoenvironnements Océaniques et Continentaux, UMR5805, CNRS - Université Bordeaux 1, \\ Avenue des Facultés, 33405 Talence, France \\ ${ }^{2}$ Geological Survey of Norway (NGU), Trondheim, Norway \\ Correspondence to: G. Milzer (gcmilzer@gmx.de)
}

Received: 30 July 2013 - Published in Clim. Past Discuss.: 13 August 2013

Revised: 4 December 2013 - Accepted: 3 January 2014 - Published: 12 February 2014

\begin{abstract}
In the present study we investigated dinocyst assemblages in the Trondheimsfjord over the last 25 to $50 \mathrm{yr}$ from three well-dated multi-cores $\left({ }^{210} \mathrm{~Pb}\right.$ and $\left.{ }^{137} \mathrm{Cs}\right)$ retrieved along the fjord axis. The downcore distribution of the dinocysts is discussed in view of changes in key hydrographic parameters of the surface waters (sea-surface temperatures (SSTs), sea-surface salinities (SSSs), and river discharges) monitored in the fjord. We examine the impact of the North Atlantic Oscillation pattern and of waste water supply from the local industry and agriculture on the fjord ecological state and thus dinocyst species diversity. Our results show that dinocyst production and diversity in the fjord is not evidently affected by human-induced eutrophication. Instead the assemblages appear to be mainly controlled by the NAO-related changes in nutrient availability and the physicochemical characteristics of the surface mixed layer. Still, discharges of major rivers have been modulated since 1985 by the implementation of hydropower plants, which certainly influences the amounts of nutrients supplied to the fjord. The impact, however, is variable according to the local geographical setting, and barely differentiated from natural changes in river run off.

We ultimately test the use of the modern analogue technique (MAT) for the reconstruction of winter and summer SSTs and SSSs and annual primary productivity (PP) in this particular fjord setting. The reconstructed data are compared with time series of summer and winter SSTs and SSSs measured at $10 \mathrm{~m}$ water depth, as well as with mean annual PPs along the Norwegian coast and in Scandinavian fjords.
\end{abstract}

The reconstructions are generally in good agreement with the instrumental measurements and observations from other fjords. Major deviations can be attributed to peculiarities in the assemblages linked to the particular fjord setting and the related hydrological structure.

\section{Introduction}

The climate of western Norway is closely coupled to the circulation of the topographically steered North Atlantic Current (NAC) and the Norwegian Coastal Current (NCC) flowing northward over the adjoining Norwegian shelf and continental margin (Loeng and Drinkwater, 2007). The lateral distribution and physico-chemical characteristics of the NCC, which is supplied by brackish water from the Baltic Sea, rivers and fjords along the Norwegian coast, are linked to the prevailing wind patterns in the North Atlantic realm (Sætre, 1999, 2007). The Trondheimsfjord in western central Norway adjoins the Norwegian Sea. The fjord hydrology is similarly coupled to the NAC and NCC circulations, as well as to local riverine input from the hinterland (Sakshaug and Myklestad, 1973; Jacobson, 1983). Fjords are relatively sheltered environments where biogenic and lithogenic sediments accumulate at very high rates (Howe et al., 2010). The fjord sediments and incorporated fossil microorganisms therefore provide highly resolved information on temporal changes in the fjord hydrology related to the proximal ocean current 
variability, and on the interaction of marine and continental climate conditions.

The distribution of organic-walled dinoflagellate cysts (or dinocysts), the zygotic products of dinoflagellates, in sediments is controlled by the surface water characteristics, making them widely used as paleoceanographic proxies for the reconstruction of sea-surface parameters (e.g. Harland, 1983; de Vernal et al., 1993; Rochon et al., 1999; Marret and Zonneveld, 2003; Zonneveld et al., 2013). Dinocysts are composed of highly resistant refractory organic matter and are therefore usually well preserved in sediments (e.g. Rochon et al., 1999; de Vernal et al., 2000; Zonneveld et al., 2007). Dinoflagellates in coastal environments are generally adapted to large sea-surface temperature (SST) and salinity (SSS) ranges due to the seasonally varying relative influence of marine/coastal and continental waters. In these settings their occurrence is therefore rather related to other species-discriminating environmental parameters than in the open ocean, such as lateral and vertical salinity gradients, nutrient availability and the species-specific ability to adapt to rapidly changing hydrological conditions (e.g. Smayda and Reynolds, 2003; Harland et al., 2004, 2006; Radi et al., 2007; Pospelova et al., 2010). These hydrological changes may however be biased by local and regional anthropogenically induced changes in the coastal and fjord environments (Sætre et al., 1997; Dale, 2001). Recent studies on surface sediments from the Trondheimsfjord which encompass the past 4-20 yr show large spatial variability in the composition of cyst assemblages linked to the complex fjord hydrography and topography (Milzer et al., 2013). Untreated waste water from local and regional industry and agriculture was directly led into the Trondheimsfjord until 1980. The assemblages, however, do not reveal any indications of human-induced eutrophication, suggesting that recently imposed environmental regulations and restrictions to reduce these nutrient inputs were highly effective (Tangen and Arff, 2003). Alternatively, the exchange of Trondheimsfjord waters with the open sea strongly dilutes excess nutrient loads, and the regular supply of oxygen-rich Atlantic waters prevents hypoxic or anoxic conditions at the bottom (Tangen and Arff, 2003).

In the following study we investigate recent changes in the dinocyst assemblages in the Trondheimsfjord over the last 25 to $50 \mathrm{yr}$ from three sediment cores located along the fjord axis. We discuss the downcore distribution of dinocysts in view of naturally and anthropogenically induced changes with regard to SST and SSS variability (monitored at three fixed mooring stations in the fjord), annual mean river discharges, atmospheric oscillation patterns (state of the North Atlantic Oscillation - NAO) and nutrient availability, which all together account for changes in the fjord ecological state (Sakshaug and Myklestad, 1973; Ottersen et al., 2001). We ultimately apply the now standard modern analogue technique (MAT) to the downcore distribution of dinocysts and test its ability to reconstruct quantitatively a series of seasurface parameters (SST, SSS and primary productivity (PP)) in this fjord setting, in order to establish a solid basis for future investigations of paleoclimate and paleoceanographic variability.

\section{Physical settings and modern hydrology}

The Trondheimsfjord extends from $63^{\circ} 40^{\prime} \mathrm{N} / 09^{\circ} 45^{\prime} \mathrm{E}$ at $\emptyset \mathrm{r}-$ land at the fjord entrance to $64^{\circ} 45^{\prime} \mathrm{N} / 11^{\circ} 30^{\prime} \mathrm{E}$ at the fjord head at Verdal (Bøe et al., 2003), and runs over into the Beitstadfjord from Skarnsund $63^{\circ} 50^{\prime} \mathrm{N} / 11^{\circ} 04^{\prime} \mathrm{E}$ until Steinkjer at $63^{\circ} 00^{\prime} \mathrm{N} / 11^{\circ} 28^{\prime} \mathrm{E}$ (Fig. 1). The fjord is $140 \mathrm{~km}$ long with an overall volume of $235 \mathrm{~km}^{3}$ and a surface area of $1420 \mathrm{~km}^{2}$. The entire fjord area is divided into three basins, the Seaward Basin, the Middle Fjord and the Beitstadfjord. The basins are separated by three sills located at the fjord entrance $(195 \mathrm{~m}$ water depth), at the island of Tautra (98 $\mathrm{m}$ water depth), and at Skarnsund (140 m water depth) (Fig. 1) (Jacobson, 1983; Ellingsen, 2004). Sediment deposition in the Trondheimsfjord is largely controlled by the prevalent currents and the associated pelagic/marine sediment load, the topography and rivers delivering large amounts of terrigenous sediment into the fjord (Bøe et al., 2003; Faust et al., unpublished data; Milzer et al., 2013). Bottom currents and tidal currents in the subsurface layers prevent the rapid deposition of the fine particle fraction in topographically elevated areas like sills. Instead, the fine particle fraction primarily accumulates in the more sheltered fjord basins. Sedimentation rates are thus higher in the Middle Fjord and Beitstadfjord than at the fjord entrance and in the Seaward Basin where several currents pass at high frequencies (Fig. 1) (Bøe et al., 2003; Milzer et al., 2013). Silt to sand microfossils, including dinocyst and foraminifera, accordingly mirror a local averaged pattern with however clear distribution gradients from the entrance to the inner part of the fjord (Milzer et al., 2013).

\subsection{Water mass exchange with the Norwegian Sea}

The hydrology of the Trondheimsfjord is characterized by a three-layer system mainly driven by density differences related to the seasonal temperature and salinity variability of the water masses inside and outside the fjord (e.g. Sakshaug and Myklestad, 1973; Strømgren, 1974; Jacobson, 1983). The bottom water is generally renewed twice a year, in February-June and September-November, by NAC and NCC waters, respectively (Sakshaug and Myklestad, 1973; Strømgren, 1974; Jacobson, 1983). The depth of the NAC and its ability to cross the sill at the Trondheimsfjord entrance depends on the depth of the overlying wedge-shaped $\mathrm{NCC}$ which, in turn, is linked to the prevailing seasonal wind patterns in the Nordic Seas (Jacobson, 1983; Sætre, 1999, 2007). In early winter-spring, when the NCC is supplied by large amounts of fresh water from the Norwegian hinterland, the current is deflected offshore by northerly winds forming a shallow surface layer. NAC waters replace the NCC 


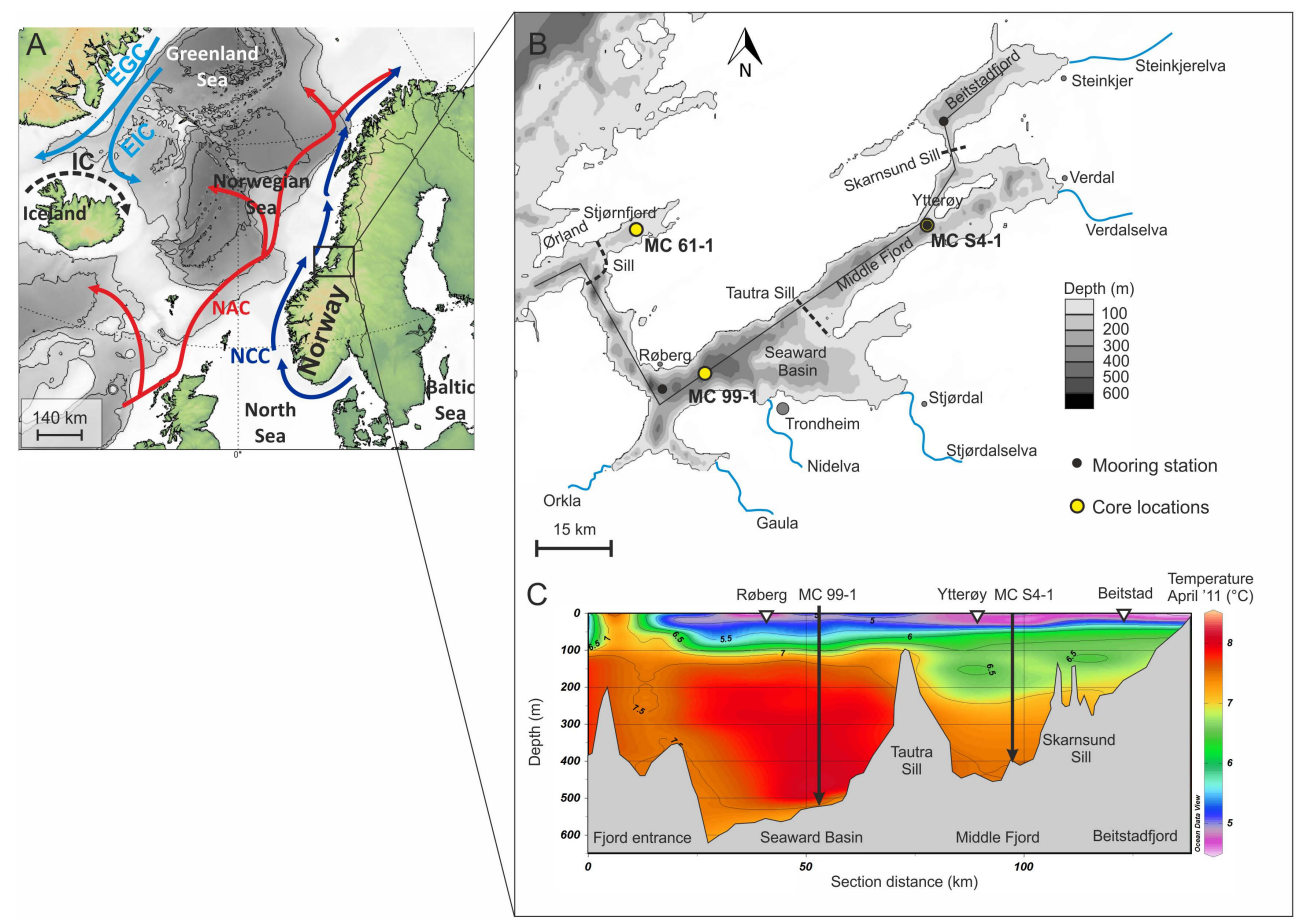

Fig. 1. (A) Surface circulation in the North Atlantic region (EGC: East Greenland Current, EIC: East Icelandic Current, IC: Irminger Current, NAC: North Atlantic Current, NCC: Norwegian Coastal Current); (B) bathymetric map of the Trondheimsfjord modified from Milzer et al. (2013). Yellow dots indicate the core locations, black dots the fixed mooring stations Røberg, Ytterøy and Beitstad referred to in the text; (C) temperature structure of the water column along the fjord axis in April 2011 (modified from Milzer et al., 2013); locations of MC 99-1 and MC S4-1 (black arrows) and the mooring stations Røberg, Ytterøy and Beitstad (white triangles) are indicated along the fjord axis. The location of MC 61-1 is outside the cross section.

at lower depths, cross the sill at the fjord entrance and renew the fjord bottom water. In late summer/early autumn, southwesterly winds induce a downwelling of the NCC, inhibiting the crossing of NAC waters over the sill. Consequently, NCC waters substitute the fjord water at intermediate depth (e.g. Sakshaug and Myklestad, 1973; Jacobson, 1983).

The intermediate/subsurface and surface waters in the Trondheimsfjord are subject to a two-layer estuarine circulation induced by large amounts of fresh water supplied by the 6 major rivers Orkla, Gaula, Nidelva, Stjørdalselva, Verdalselva and Steinkjerelva (Fig. 1) with a mean annual runoff of $725 \mathrm{~m}^{3} \mathrm{~s}^{-1}$ and up to $6430 \mathrm{~m}^{3} \mathrm{~s}^{-1}$ during spring (Ellingsen, 2004 and references therein; Pettersson, 2012). Tidal surface currents are considered to be the main force for internal mixing with a semidiurnal sea level change of ca. $1.8 \mathrm{~m}$ (Jacobson, 1983). The tidal currents flow anti-clockwise, entering the fjord on its southern edge during flood and flowing out along the northern edge during ebb (Jacobson, 1983).

\subsection{Surface water characteristics over the past $50 \mathrm{yr}$}

The temperature and salinity structures as well as the nutrient content in the surface waters vary seasonally associated with coastal water exchange, riverine input and internal mixing (Sakshaug and Myklestad, 1973; Strømgren, 1974; Jacobson,
1983). These processes, in turn, are to a large extent controlled by the prevalent winter NAO pattern of atmospheric variability (Ottersen et al., 2001). During a positive NAO phase, the Norwegian climate is dominated by marine warm and wet air masses from lower latitudes causing strong precipitation and continental runoff (e.g. Hurrell and van Loon, 1997; Ottersen et al., 2001). During a negative oscillation state, Norway is affected by pulses of cold and dry continental air masses resulting in extremely low temperatures and reduced continental runoff. This atmospheric influence explains to a high extent the modern mean annual SST and SSS variability over the Norwegian margin and the adjoining coastal systems (Blindheim et al., 2000; Visbeck et al., 2003). Contrary to the deep water layers, which are largely decoupled from the surface layers after the bottom water exchange, SSTs and SSSs strongly vary seasonally and annually in the Trondheimsfjord (Jacobson, 1983). According to instrumental measurements obtained from mooring stations within the Trondheimsfjord (Fig. 2), SSSs and SSTs at $10 \mathrm{~m}$ water depth display a minor long-term salinity decrease $(<0.5 \mathrm{PSU})$ and temperature increase $\left(\mathrm{ca} .1^{\circ} \mathrm{C}\right)$ from 1963 to 2005 (data from Trondhjem Biological Station of the Norwegian University of Science and Technology (NTNU): http: //www.ntnu.edu/biology/tbs). On an annual to decadal scale, 

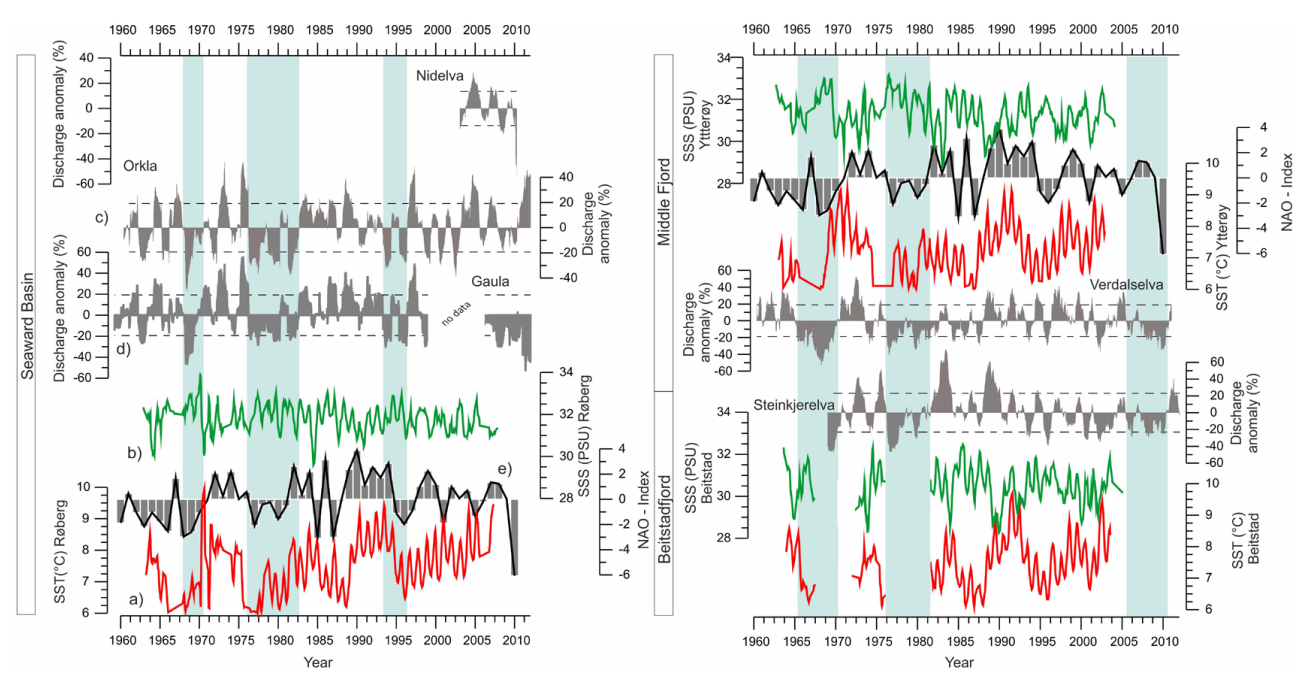

Fig. 2. Hydrological and climatic data at mooring stations Røberg, Ytterøy and Beitstad at $10 \mathrm{~m}$ water depth from 1963 to 2005 with (a) red lines: 15 pt. running average of monthly temperature data, (b) green lines: 7 pt. running average of monthly salinity data, (c) grey shaded graphs: annual running average of river discharge rate anomalies $\left(\mathrm{m}^{3} \mathrm{yr}^{-1}\right.$ in $\%$ below/above the $50 \mathrm{yr}$ mean value), (d) grey dashed lines: standard deviation of river discharge rates in \%; (e) grey black-framed columns: NAO index (Hurrell, 1995); blue columns: negative anomalies of river discharge.

mean annual river discharges (data from the Norwegian Water Resources and Energy Directorate (NVE): www.nve.no) are lowest when the NAO is in its negative state and highest during a positive oscillation phase. This NAO-forced variability in river discharges is concomitant with the SST and SSS fluctuations with increased consistency towards the inner fjord (Fig. 2). Calculated correlation coefficients between the NAO index, river discharge, SST and SSS are, however, low around $R^{2}=0.3-0.6(p<0.05)$, with randomly higher values during spring and autumn around $R^{2}=0.6-$ $0.9(p<0.05)$. Annual to multi-annual SST changes correspond best with the NAO pattern in winter (with maximum values around $R^{2}=0.6, p<0.05$ ), suggesting a major influence of atmospheric temperatures on the thermal signature of the surface waters. These low correlation factors can be explained by the complex and often indirect ecological and environmental responses to NAO changes which may result in relatively low values despite a proven impact (Ottersen et al., 2001). Nevertheless, the relationship between NAO phases, river discharges, SST and SSS changes seems to be best established before 1980. This might be explained either by the long-term negative NAO phase until ca. 1982, which imposed a higher climatic stress on the fjord surface water, or, alternatively, by the implementation of local hydropower plants in the early 80s such as in the Orkla river, which modifies the river input (L'Abée-Lund et al., 2009) (Fig. 2).

A proper investigation of the NAO impact (and associated precipitation and atmospheric temperature changes) on the quantity and type of nutrients in the fjord surface mixed layer is not possible yet, due to the lack of time series of nutrient concentrations. Short-term observations by Sakshaug and
Myklestad (1973) in 1970/71, however, showed that nutrients such as nitrite, nitrate, orthophosphate and silicate, fluctuate seasonally according to the depth and stability of the pycnocline and riverine input. The supply of $\mathrm{NO}_{3}-\mathrm{N}$ and $\mathrm{PO}_{4}-\mathrm{P}$ to the Seaward Basin from continental runoff and rivers roughly amounted to $1.2-7.0 \mathrm{tday}^{-1}$ and below $0.15 \mathrm{tday}^{-1}$, respectively, with maxima in late spring and autumn. Sewage supplied directly to the outer fjord yielded ca. 2.5 and $0.75 \mathrm{t}$ daily of total N and total P, respectively (Sakshaug and Myklestad, 1973).

\section{Material and methods}

Three sediment cores were retrieved along the fjord axis, in Stjørnfjord at the fjord entrance, in the central Seaward Basin and in the Middle Fjord (Fig. 1, Table 1) with a multi corer as part of a research cruise of the research vessel FF Seisma from the Geological Survey of Norway (NGU) in April 2011. The sediment cores were sub-sampled on board at $1 \mathrm{~cm}$ intervals and split into two halves later in the lab, one for radiometric dating and one for dinocyst census counts. The sediment samples were freeze-dried in order to save as much material as possible for dinocyst census counts.

\subsection{Chronology and sediment accumulation rates}

Activities of ${ }^{210} \mathrm{~Pb},{ }^{226} \mathrm{Ra},{ }^{137} \mathrm{Cs}$ and ${ }^{232} \mathrm{Th}$ were measured in ca. $4-5 \mathrm{~g}$ of dried bulk sediment using a low background, high-efficiency, well-shaped $\gamma$ detector (Schmidt et al., 2013). Activities are expressed in $\mathrm{mBq} \mathrm{g}^{-1}$ and errors correspond to $1 \mathrm{SD}$ counting statistics. The detector was 
Table 1. Site locations, water depths and core lengths.

\begin{tabular}{llcccc}
\hline Multi-core & Location & $\begin{array}{c}\text { Longitude } \\
{\left[{ }^{\circ} \text { East }\right]}\end{array}$ & $\begin{array}{c}\text { Latitude } \\
{\left[{ }^{\circ} \text { North }\right]}\end{array}$ & $\begin{array}{c}\text { Water } \\
\text { depth }[\mathrm{m}]\end{array}$ & $\begin{array}{c}\text { Core } \\
\text { length }(\mathrm{cm})\end{array}$ \\
\hline MC 61-1 & Stjørnfjord & 9.86 & 63.71 & 225 & 12 \\
MC 99-1 & Seaward Basin & 10.19 & 63.48 & 504 & 24 \\
MC S4-1 & Middle Fjord & 10.98 & 63.73 & 420 & 40 \\
\hline
\end{tabular}

calibrated using IAEA standards (RGU-1; RGTh; SOIL-6). Excess of ${ }^{210} \mathrm{~Pb}\left({ }^{210} \mathrm{~Pb}_{\mathrm{xs}}\right)$ was calculated as the difference of the total activity of ${ }^{210} \mathrm{~Pb}$ in the sediment and the supported activity by its parent isotope ${ }^{226} \mathrm{Ra}$. The error on ${ }^{210} \mathrm{~Pb}_{\mathrm{xs}}$ therefore corresponds to the propagation of errors in measured ${ }^{210} \mathrm{~Pb}$ and ${ }^{226} \mathrm{Ra}$ activities.

The dating of the multi-cores relies on ${ }^{210} \mathrm{~Pb}$, a naturally occurring radionuclide in the sediment with a halflife of $22.3 \mathrm{yr}$. This method is commonly used to estimate short-term (years to decades) sediment accumulation rates in continental and oceanic environments for the last $40 \mathrm{yr}$ (Appleby, 2001). Briefly, dating is calculated using the excess activity of ${ }^{210} \mathrm{~Pb}\left({ }^{210} \mathrm{~Pb}_{\mathrm{xs}}\right)$ which derives from atmospheric fallout and water column scavenging, and is rapidly incorporated into the sediment. The unsupported ${ }^{210} \mathrm{~Pb}$ incorporated into the sediment decays with time according to its half-life. In order to estimate ages and/or sediment accumulation rates, several models have been developed assuming different hypotheses such as constant initial concentration (CIC model), constant rate of supply (CSR model) or constant flux and constant sedimentation (CF:CS model) (Kirchner, 2011, among others). In this study we applied the CF:CS model and examined its accuracy in dating of the sedimentary archives using ${ }^{137} \mathrm{Cs}\left(\mathrm{T}_{1 / 2}=30 \mathrm{yr}\right)$ (e.g. Robbins and Edgington, 1975; Durantou et al., 2012). This artificial radionuclide serves as an independent time-stratigraphic marker due to elevated activity peaks associated with nuclear weapon test fallouts (maximum in 1963) and the Chernobyl accident in 1986 (Durantou et al., 2012).

\subsection{Dinocysts: sample preparation and ecological background}

Dinoflagellate cysts were retrieved from the $<150 \mu \mathrm{m}$ fraction. The treatment of the samples follows a standard sample preparation procedure (e.g. Stockmarr, 1971; de Vernal et al., 1996), slightly modified at EPOC/Université Bordeaux 1 (Penaud et al., 2008, http://www.epoc.u-bordeaux.fr/index. php?lang=frl\&page=eq_paleo_pollens). The samples were treated with cold hydrochloric acid $(\mathrm{HCl})(10,25$ and $50 \%)$ and cold 40 and $70 \%$ hydrogen fluoride (HF) to dissolve carbonates and silicates and washed through a $10 \mu \mathrm{m}$ nylon mesh. The residue was centrifuged and additionally swirled in a large watch glass to remove high amounts of amorphous organic material (AOM) (Riding and Kyffin-Hughes,
2004; Milzer et al., 2013). The final residue was mounted with glycerine jelly between microscope slides. On average, 300 cysts per slide were counted using a Zeiss Axioscope light microscope at $40 \times$ magnification. Absolute abundances (cysts $\mathrm{cm}^{-3}$ ) of dinocysts and palynomorphs were calculated using the Lycopodium marker grain method (Stockmarr, 1971). Relative abundances (\%) of each species were calculated including only dinocysts.

The taxonomical nomenclature corresponds to Rochon et al. (1999) and Head et al. (2001, 2006). Operculodinium centrocarpum s.l. includes the long- and short-process forms of $O$. centrocarpum sensu (Wall and Dale, 1967) and $O$. centrocarpum - Arctic morphotype (de Vernal et al., 2001). Dinocyst species within the Spiniferites, Selenopemphix, Islandinium, Brigantedinium and Impagidinium taxa were grouped according to Marret and Zonneveld (2003), as summarized in Milzer et al. (2013). The resulting species richness in the studied sediment cores from the Trondheimsfjord amounted to a maximum of 17 dinocyst taxa and 4 Chlorophycean and Prasinophyceae species. The spatial distribution of the dominant species in surface sediments of the Trondheimsfjord was recently discussed by Milzer et al. (2013). The following section summarizes the ecology and environmental background of each recognized species. Unless otherwise specified, most information is taken from Matthiessen (1995), Rochon et al. (1999), Marret and Zonneveld (2003), de Vernal and Marret (2007), van Nieuwenhove et al. (2008), and Zonneveld et al. (2013).

Pentapharsodinium dalei is associated with cold and stratified waters as typical for Norwegian fjords and other temperate and polar embayments. The species belongs to the autotrophic taxa and generally blooms in spring/early summer when surface waters contain high amounts of nutrients from previous winter mixing. The autotrophic species $O p$ erculodinium centrocarpum is considered as a cosmopoli$\tan$ species which is able to adapt quickly to environmental changes, and is therefore often observed in coastal waters and/or at the coastal/oceanic boundary (Wall and Dale, 1967; Dale et al., 2002, 1999b). In the Nordic Seas this species is associated with the pathway of the warm and saline waters carried by NAC (de Vernal et al., 2000). Selenopemphix quanta s.l. is a heterotrophic species which has been mainly documented from subtropical coastal areas in regions characterized by mesotrophic to eutrophic conditions. The abundance of the heterotrophic species Brigantedinium 
spp. largely depends on the presence of diatom preys whose occurrence is similarly linked to nutrient enrichment in the photic layer in various environments (e.g. regions of enhanced upwelling, sea-ice edge zones, etc.). The heterotrophic taxon Islandinium minutum shows a bipolar distribution in coastal areas north of $30^{\circ} \mathrm{N}$ and south of $30^{\circ} \mathrm{S}$, withstanding large (inter-)seasonal fluctuations of temperature, salinity, insolation, nutrient concentration, and long seaice cover extension. Cysts of Lingulodinium machaerophorum are reported to be restricted to regions with summer temperatures above $10-12^{\circ} \mathrm{C}$. An enhanced occurrence of $L$. machaerophorum in southern Norwegian fjords has been related to eutrophication due to industrial and agricultural activity (Sætre et al., 1997; Dale et al., 1999a), and along other coastal areas to increased freshwater advections (Zaragosi et al., 2001; Lezine et al., 2005). Ataxiodinium choanum is a coastal to open oceanic fully marine species with highest relative abundances in eutrophic environments (Marret et al., 2004). In this study the species is most likely related to an enhanced influence of Atlantic-derived waters. Cysts of Nematosphaeropsis labyrinthus are generally linked to outer neritic to oceanic environments and to eutrophic conditions within the North Atlantic ocean (Devillers and de Vernal, 2000). The Spiniferites taxa are dominated by Spiniferites ramosus and Spiniferites elongatus. Spiniferites ramosus s.l. is considered as a cosmopolitan species linked to upwelling or a well-mixed surface water layer resulting in mesotrophic to eutrophic conditions. Nowadays highest occurrence of S. elongatus s.l. is found around Iceland, potentially indicating a preference to colder and lower salinity but eutrophic surface water conditions (Marret et al., 2004). Cysts of Spiniferites lazus, Spiniferites mirabilis, Spiniferites membranaceus and Spiniferites delicatus are associated with marine warm and saline waters in oligo-/mesotrophic environments. $S$. bentorii is associated with coastal high productivity environments and has been found in Saanich Inlet (B.C. Canada). Since the total abundance of these Spiniferites taxa in the Trondheimsfjord does not exceed $3 \%$, we relate their presence to a stronger marine/coastal influence in surface layers assigned as the combined term Spiniferites " $A W$ " without distinguishing their particular species-specific characteristics. All species grouped within Impagidinium spp. generally thrive in fully marine environments (rarely neritic) with oligotrophic to eutrophic conditions. The distribution of Bitectatodinium tepikiense is related to the transitional zone between the subpolar and temperate zones in the Norwegian Sea (Grøsfjeld and Harland, 2001). Higher abundances of this species may indicate a strong seasonal temperature gradient with enhanced surface water stratification. Cysts of Polykrikos schwartzii are generally found in sediments from subtropical to temperate continental shelves, estuaries and shelf seas throughout the world except for polar seas, characterized by a high nutrient level as well as turbulent waters (Matsuoka et al., 2009). Cysts of Alexandrium tamarense are reported in coastal sediments of temperate/subtropical re- gions with brackish to fully marine, oligotrophic to eutrophic environments from the coasts of e.g. Germany, Sweden, and Spain (Nehring et al., 1997 and references therein). The increased abundance of Halodinium minor, Radiosperma corbiferum and Hexasteria problematica is related to moderate salinity and high nutrient content in surface waters in transitional brackish to marine environments (e.g. Parke and Dixon, 1964; McMinn, 1991; Matthiessen, 1995; Price and Pospelova, 2011; Sorrel et al., 2006)

\subsection{Multivariate analyses}

Multivariate analyses were applied to the cyst assemblages in order to extract major patterns in species abundances, and to investigate their spatio-temporal organization according to the various environmental settings of the studied sediment cores. The analyses were conducted using the R Project free software package for statistical computing, version 3.0.0 (R Development Core Team, 2008, http://www.r-project.org/) and paleontological statistics software "PAST" (http://folk. uio.no/ohammer/past/) by Hammer et al. (2001). Since dry bulk density measurements were only conducted in one core (MC 99-1), it was not possible to calculate the species accumulation rates in all cores based on the cyst concentrations. All statistical analyses were therefore conducted using the relative cyst abundances only, i.e. they refer to the composition of the assemblages but not to the rate of species accumulation (flux) at the sediment water interface. The statistically based classification of the investigated sediment samples was carried out on both the separate data sets related to single sediment cores, and the combined cyst assemblages obtained from the three studied multi-cores. The latter were analysed using correspondence analysis (CA) in order to constrain samples (years) in terms of characteristic species and their associated ecological, environmental and stratigraphic contexts in the Trondheimsfjord (Hammer et al., 2001). However, differences between the samples and the core sites are relatively small. We therefore additionally performed a cluster analysis on the data set of every single sediment core using the Bray-Curtis dissimilarity index to more objectively highlight the differences of the assemblages.

\subsection{Quantitative reconstructions of the sea-surface parameters SST, SSS and PP}

The modern analogue technique (MAT) was applied to the relative dinocyst abundances in the studied sediment cores for quantitative reconstructions of winter and summer SSS and SST, and annual primary productivity (PP) (de Vernal et al., 2001; Radi and de Vernal, 2004; Guiot and de Vernal, 2007). The MAT method was successfully developed for the reconstruction of the sea-surface parameters in open ocean conditions for most of the existing set of marine microfossils (e.g. Imbrie and Kipp, 1971; Birks, 1995; Maslin et al., 1995; Pflaumann et al., 1996; Kucera et al., 2005; 
Waelbroeck et al., 2005; Guiot and de Vernal, 2007; Telford and Birks, 2011). The application of MAT in this work is considered as an initial test of the potential and the quality of dinocyst-based reconstructions of sea-surface parameters in fjord environments using transfer functions. We therefore strictly followed the standard procedure according to de Vernal et al. (2001) and Guiot and de Vernal (2007) using one of their most recently validated $n=1207$ databases (see the successive steps in the construction of the modern database at http://www.geotop.ca/fr/bases-de-donnees/ dinokystes.html; see also Radi and de Vernal, 2008; Radi et al., 2009; Bonnet et al., 2009) as summarized as follows: Hydrographic (summer and winter SST and SSS) and annual primary productivity data at $0 \mathrm{~m}$ water depth, which were averaged over the period 1900 to 2001 (NODC, 2001), and 2002 to 2005 (VGP model applied to MODIS chlorophyll data), respectively, were assigned to each of the reference modern sites (i.e. analogues). The sea-surface conditions were reconstructed from the fossil records with regard to the similarity to the modern dinocyst spectra. In order to determine the best number of analogues to retain with regard to the estimated values and the associated degree of accuracy, we conducted MAT with different numbers of analogues (Table 2). The maximum weight is given for the closest analogue in terms of statistical distance and the associated range of the environmental parameters. Best results for the seasurface parameter reconstructions and the associated errors were achieved using 5 analogues as previously tested with the other databases (see de Vernal et al., 2000, 2001). This choice was justified after several tests done to determine the best number of analogues according to a compromise regarding the degree of accuracy of estimations (Table 2). A minimum number of analogues (3) minimized the error bar on reconstructions but is not statistically robust, whereas a number of analogues $>5$ (e.g. 10) provided an artificially high error bar. Reconstructed values based on the assemblages from the different core locations using 3,5 and 10 analogues also did not reveal large differences but, in turn, confirmed the use of 5 analogues for the estimation of the sea-surface parameters as a relative mean/compromise. The associated estimated parameters are presented as the weighted averaged values and the related minimum and maximum values, e.g. SST, min. SST and max. SST found in the 5-analogue set (Table 3). The accuracy of the approach is assessed by the correlation coefficient between observed and estimated values for each reconstructed parameter when the test is performed on the calibration data set (i.e. the modern database excluding the spectrum to analyse, see de Vernal et al., 2001, 2005). This step furthermore provides residual differences between observations and estimates from which is derived the root mean square error (RMSE), equivalent to the standard deviation of these residuals (e.g. de Vernal et al., 2001, 2005; Radi and de Vernal, 2004; Guiot and de Vernal, 2007). Additionally, we tested our data for the risk of autocorrelation by running the MAT with the reference data sets without (1) the identified analogues sites in the Norwegian Sea and (2) sites with the highest recall ratio.

The MAT was run using R Project for statistical computing, version 3.0.0 (R Development Core Team, 2008, http://www.r-project.org/) and a script developed by J. Guiot in the BIOINDIC package (https://www.eccorev.fr/ spip.php?article389). We calculated the reconstructions of winter and summer SSTs and SSSs as well as PPs using the original data set of Radi and de Vernal (2008) collected in the northern hemisphere of the North Atlantic, Arctic and North Pacific oceans with additional data points (database available from the DINO9 workshop: http://www.geotop.ca/upload/files/babillard/congres_ et_ateliers/Handout\%20Dino9-Workshop.pdf), bringing the total number of sites to 1207 . With this database, most accurate reconstructions (based on linear regressions of estimated vs. observed data) can be achieved for winter and summer SSTs with $R^{2}=0.95$ and $\mathrm{RMSEP}=1.1^{\circ} \mathrm{C}$, and $R^{2}=0.96$ and RMSEP $=1.49^{\circ} \mathrm{C}$, respectively. Summer SSSs similarly reveal a good accuracy with $R^{2}=0.74$ and RMSEP $=2.40$ PSU. The lowest accuracy was achieved for winter SSSs with $R^{2}=0.69$ and RMSEP $=2.30$ PSU. The validation test for the reconstruction of primary productivity yields a good accuracy with $R^{2}=0.84$ and quite a large $\mathrm{RMSEP}=54.58 \mathrm{~g} \mathrm{C} \mathrm{m}^{-2} \mathrm{yr}^{-1}$ (Table 2).

In a final step we compared separately the reconstructed values with the associated measured time series monitored at $10 \mathrm{~m}$ water depth at the respective mooring stations (Røberg for core MC 61-1 and MC 99-1, Ytterøy for core MC S4-1) and tested the similarity using the Mann-Whitney (Wilcoxon) test (Bigler and Wunder, 2003; von Detten et al., 2008).

\section{Results and discussion}

\subsection{Chronologies and sediment accumulation rates}

${ }^{210} \mathrm{~Pb}_{\mathrm{xs}}$ activities in MC 99-1, in the Seaward Basin, range from 37 to $159 \mathrm{mBq} \mathrm{g}^{-1}$, decreasing downcore according to the radioactive decay of ${ }^{210} \mathrm{~Pb}$ with time (Fig. 3). With regard to the CF:CS model, the sediment accumulation rate in MC 99-1 is $0.49 \mathrm{~cm} \mathrm{yr}^{-1}$ and encompasses the last $49 \mathrm{yr}$. The counting error increases downcore, reaching up to max. $3.5 \mathrm{yr}$ (Fig. 3). The ${ }^{137} \mathrm{Cs}$ profile in MC $99-1$ shows remarkable peak activities with maximum values of $53-59 \mathrm{mBq} \mathrm{g}^{-1}$ at $12-13 \mathrm{~cm}$ and of $36-37 \mathrm{mBq} \mathrm{g}^{-1}$ at $23-24 \mathrm{~cm}$ sediment depths. According to the ${ }^{210} \mathrm{~Pb}_{\mathrm{xs}}$-based dating, sediments at these depths correspond to an age of $1986 \pm 1.7 \mathrm{yr}$ and ca. $1963-1965 \pm 3.4 \mathrm{yr}$, respectively, which is in good agreement with the known nuclear power plant accident in Chernobyl (1986) and the nuclear weapon test fallouts (max. in 1963) (Fig. 3).

Activities of ${ }^{210} \mathrm{~Pb}_{\mathrm{xs}}$ at the fjord entrance (core MC 61-1) decrease continuously with depth from 132 to $69 \mathrm{mBqg}^{-1}$. 
Table 2. Results of validation test for the reconstructions of the winter and summer sea-surface temperature (SST) parameters, salinity, and primary productivity based on the database comprising 1207 reference sites (see Sect. 3.4) with 3, 5 and 10 analogues; $R^{2}$ is the correlation coefficient between observed and estimated values. The RMSEP (Root Mean Square Error of Prediction) is calculated by dividing the database into calibration and verification data sets. $\Delta$ mean refers to the mean of the ranges between the estimated minimum and maximum values.

\begin{tabular}{lccccccccc}
\hline & \multicolumn{3}{c}{ MAT_5 analogues } & \multicolumn{2}{c}{ MAT_3 analogues } & \multicolumn{3}{c}{ MAT_10 analogues } \\
\hline Environmental parameters & $R^{2}$ & RMSEP & $\Delta$ mean & $R^{2}$ & RMSEP & $\Delta$ mean & $R^{2}$ & RMSEP & $\Delta$ mean \\
\hline Winter SST & 0.95 & 1.05 & 1.97 & 0.98 & 1.06 & 1.25 & 0.97 & 1.09 & 3.13 \\
Winter SSS & 0.69 & 2.3 & 2.70 & 0.67 & 2.35 & 1.82 & 0.71 & 2.21 & 3.99 \\
Summer SST & 0.96 & 1.49 & 3.10 & 0.96 & 1.50 & 2.02 & 0.96 & 1.53 & 4.78 \\
Summer SSS & 0.74 & 2.4 & 3.39 & 0.73 & 2.46 & 2.24 & 0.75 & 2.38 & 5.08 \\
Primary productivity & 0.84 & 54.58 & 100.09 & 0.83 & 56.09 & 64.67 & 0.83 & 35.76 & 151.85 \\
\hline
\end{tabular}

The deepest layer of core MC6 1-1 $(10.5 \mathrm{~cm})$ shows an increase in activity $\left(82 \mathrm{mBq} \mathrm{g}^{-1}\right)$ with a concomitant increase in ${ }^{232} \mathrm{Th}$ (data not shown). The long-lived ${ }^{232} \mathrm{Th}$ occurs naturally and is usually associated with the detrital fraction. Variations in ${ }^{232} \mathrm{Th}$ activities are thus assumed to trace changes in the detrital fraction proportion (Bayon et al., 2009 and references therein). Sedimentation rate in MC 61-1 was therefore estimated based on ${ }^{210} \mathrm{~Pb}_{\mathrm{xs}}$ activities normalized by the measured ${ }^{232} \mathrm{Th}$ activities to correct for any deviations related to substrate changes (Fig. 3). The corresponding sediment accumulation rate yields $0.46 \mathrm{~cm} \mathrm{yr}^{-1}$. The $12 \mathrm{~cm}$-long sediment core thus comprises the past $25 \mathrm{yr}( \pm \max .1 .1 \mathrm{yr})$. The time period encompassed in this sedimentary archive is too short to reveal peak activities associated with the Chernobyl accident or past nuclear weapon tests. The absence of activity peaks in the ${ }^{137} \mathrm{Cs}$ profile, however, serves as an indirect validation (Fig. 3).

The activities of ${ }^{210} \mathrm{~Pb}_{\mathrm{xs}}$ in MC S4-1 in the Middle Fjord range from 44 to $11 \mathrm{mBqg}^{-1}$ from the sediment surface to the lowermost depths, with fairly low activities from 11 to $16 \mathrm{mBqg}^{-1}$ at depths deeper than $28 \mathrm{~cm}$ (Fig. 3). The core is located in a deep basin surrounded by hills, and the river Verdalselva discharges significant amounts of fresh water and terrigenous sediments from the hinterland into the Middle Fjord. We assume that relatively low ${ }^{210} \mathrm{~Pb}_{\mathrm{xs}}$ activities as well as the changes in the activity profile below $28 \mathrm{~cm}$ sediment depths may be related to changes in sediment source and delivery. We therefore normalized the measured ${ }^{210} \mathrm{~Pb}_{\mathrm{xs}}$ activities with the depth-related activities of the detrital tracers ${ }^{232} \mathrm{Th}$ similarly to the chronology in MC 61-1. The sedimentation rate in the $38 \mathrm{~cm}$-long multi-core MC S41 yields $0.68 \mathrm{~cm} \mathrm{yr}^{-1}$ and consequently encompasses the last 55 years with a maximum error of $\pm 5 \mathrm{yr}$ (increasing downcore). Peak activities of ${ }^{137} \mathrm{Cs}\left(54 \mathrm{mBq} \mathrm{g}^{-1}\right)$ at depths of $16-$ $18 \mathrm{~cm}$ (according to the chronology accomplished by correcting for changes in the detrital fraction) correspond to the years 1985-1987 and can thus be attributed to the Chernobyl accident in 1986 (Fig. 3). At depth 31-32 cm the expected peak related to fallout tests is not well expressed. However, the occurrence of detectable ${ }^{137} \mathrm{Cs}$ activities testifies to sediments deposited after 1950.

\subsection{Dinocyst concentrations and preservation}

Palynomorphs identified within the studied cores are mainly dominated by dinocysts, whereas Chlorophycean and Prasinophyceae algae rarely account for $5 \%$ of the total palynological assemblages (excluding pollens). The following information will therefore only relate to dinocysts. Maximum absolute abundances of dinocysts were found in MC 61-1 in Stjørnfjord at the fjord entrance, fluctuating between ca. 10000 and 130000 specimens $\mathrm{cm}^{-3}$ with mean concentrations of 72000 specimen $\mathrm{cm}^{-3}$ (Fig. 5). Values were significantly lower in the cores located in the Middle Fjord and the Seaward Basin, with mean dinocyst concentrations of 25000 specimens $\mathrm{cm}^{-3}$ (MC S4-1) and 14000 specimens $\mathrm{cm}^{-3}$ (MC 99-1) (Figs. 6, 7).

These relatively high mean concentrations correspond well to observations by Dale (1976) from a limited set of surface samples, and our own analysis based on 59 surface samples evenly distributed in the Trondheimsfjord (Milzer et al., 2013), as well as to concentrations observed in inner shelf and fjord environments along the Norwegian coast by Grøsfjeld and Harland (2001). Differences in mean cyst concentrations among the studied multi-cores are most likely mainly related to dilution linked to the current circulation features, and to the proximity of river inlets and associated nutrient and terrigenous sediment loads. Highest absolute cyst abundance and largest species evenness are observed in MC 61-1 in Stjørnfjord at the fjord entrance and can be related to the proximity of the Norwegian Sea. Stjørnfjord is easily flushed with Atlantic water and is likely to experience a periodical coastal upwelling resulting in an enhanced nutrient availability. Additionally, the dilution of marine biogenic material by terrestrial organic and lithogenic particles might be limited (sediment accumulation is lowest at site MC $61-1\left(0.46 \mathrm{~cm} \mathrm{yr}^{-1}\right)$ due to the absence of major river inlets in Stjørnfjord, contrary to the inner parts of 

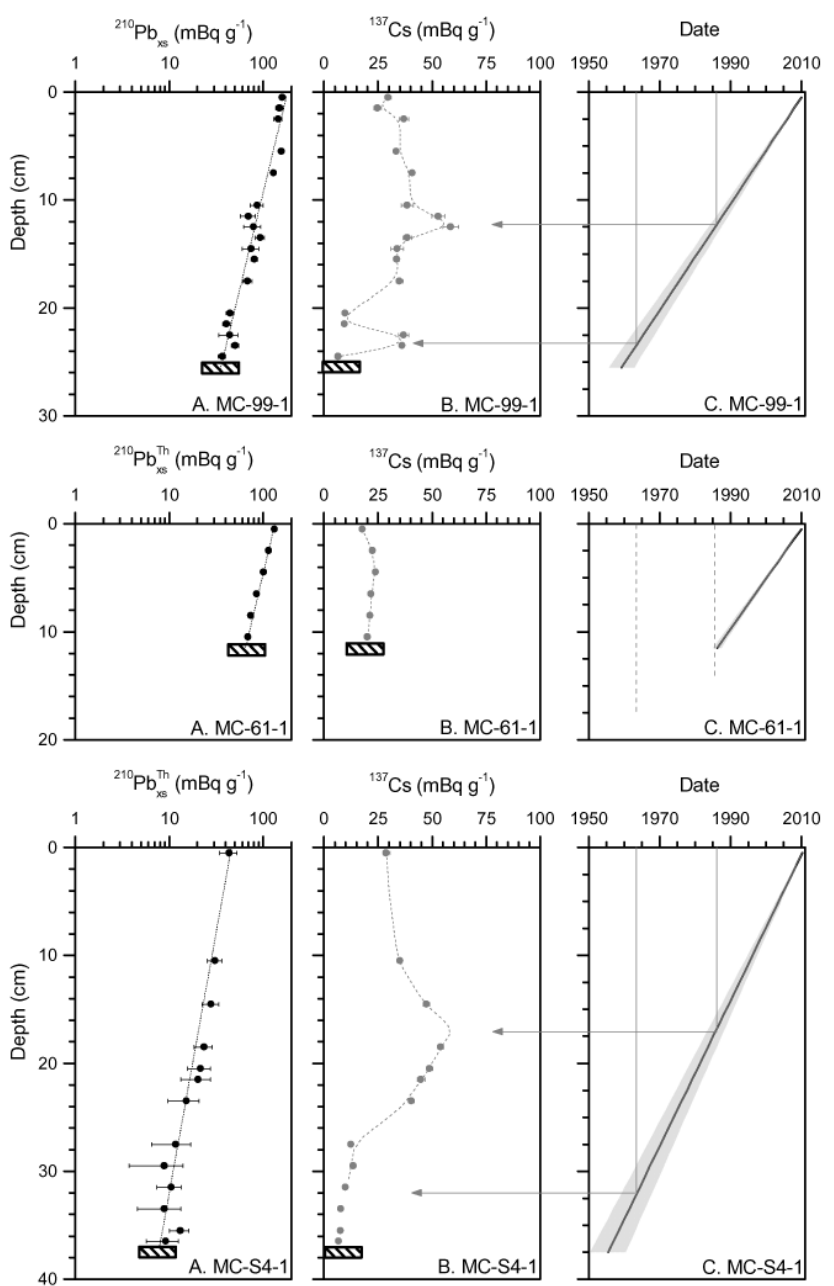

Fig. 3. Core chronology of MC 61-1 (centre) at the fjord entrance, MC 99-1 (top) in the Seaward Basin and MC S4-1 (bottom) in the Middle Fjord, showing (A) ${ }^{210} \mathrm{~Pb}_{\mathrm{xs}}$ or ${ }^{210} \mathrm{~Pb}_{\mathrm{xsTh}}$ (i.e. ${ }^{210} \mathrm{~Pb}_{\mathrm{xs}}$ normalized to ${ }^{232} \mathrm{Th}$, explanation in the text) profiles, (B) ${ }^{137} \mathrm{Cs}$ profiles (except for MC 61-1) and (C) calculated ages based on the $\mathrm{CF}$ :CS model. The arrows indicate the expected position of the ${ }^{137} \mathrm{Cs}$ peaks related to maximum weapon test atmospheric fallout and the Chernobyl accident according to the chronology based on ${ }^{210} \mathrm{~Pb}_{\mathrm{Xs}}$.

the Trondheimsfjord. The Seaward Basin receives discharges from 4 of the 6 major rivers which end in the Tronsheimsfjord (Fig. 1). Associated nutrient and terrigenous loads as well as dinocysts thriving in the surface layers are distributed across the fjord, linked to the general circulation pattern of the surface currents during flood tide (Jacobson, 1983). Sediment (sedimentation rate in core MC 99-1: $0.49 \mathrm{~cm} \mathrm{yr}^{1}$ ) and cyst accumulation in the deep Seaward Basin is thus limited despite the proximity of major river inlets. Moreover, the observed relatively low cyst concentrations measured at site MC 99-1 $\left(\right.$ mean $=14000$ cysts $\left.\mathrm{cm}^{-3}\right)$ can also be explained by dilution by fine sediments carried into the fjord basin during bottom water renewal events.

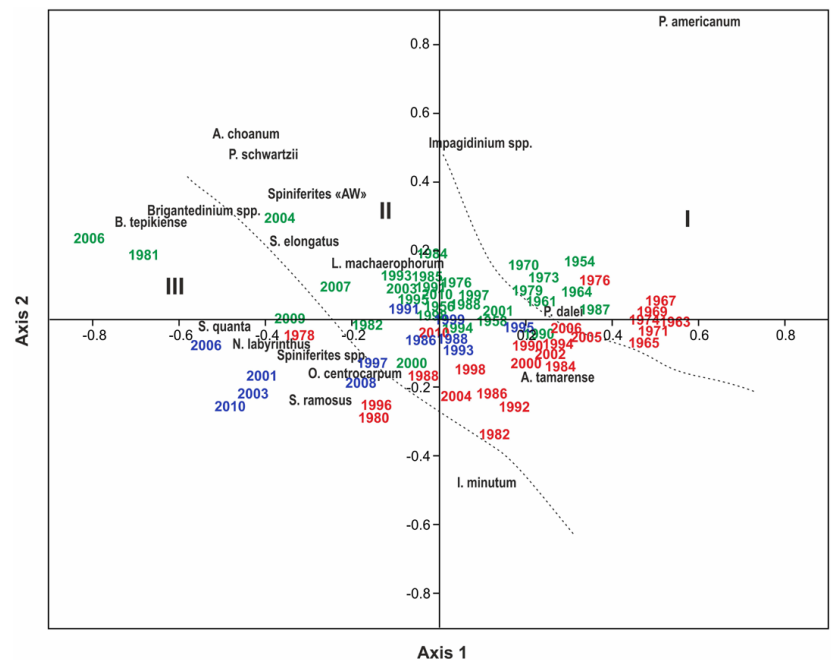

Fig. 4. Correspondence analysis based on relative cyst abundances of all cores combined as one data set. The species are ordinated by the CA according to abundance and downcore variability of cysts. The coloured numbers are organized by sediment cores: MC 611: blue; MC 99-1: red; and MC S4-1: green; samples belonging to group I are placed on the positive axis 1 in correspondence with the dominance of $P$. dalei, minimum abundances or absence of other taxa; samples categorized into group II are placed mainly in the centre of the CA and are characterized by a successive decrease in $P$. dalei and consequently higher abundances of most of the other species. Samples representative of group III with the highest cyst evenness are located on the far negative axis 1 .

The Middle Fjord is more sheltered than the Seaward Basin, with relatively high riverine (and nutrient) input and high sedimentation rates (MC S4-1: $0.68 \mathrm{~cm} \mathrm{yr}^{-1}$ ). Cyst concentrations are, nevertheless, relatively low and we assume that cyst assemblages in the Middle Fjord are subject to dilution due to the large sediment input from the hinterland.

Ultimately, the preservation ability against postdepositional degradation due to sediment oxygenation may alter the original cyst assemblages (Zonneveld et al., 1997, 2001). The dominant species in the Trondheimsfjord, $P$. dalei, is considered to be relatively resistant to aerobic decay, in contrast to the moderately sensitive cysts of $O$. centrocarpum, L. machaerophorum, and the highly sensitive Brigantedinium spp. species (Zonneveld et al., 1997, 2008). Post-depositional degradation may thus contribute to the relatively poor cyst evenness in the fjord sediments. Still, the relatively high sedimentation rates might limit degradation processes by minimizing the time organic remains are exposed to oxygen in the bottom and pore waters (Blume et al., 2009). 


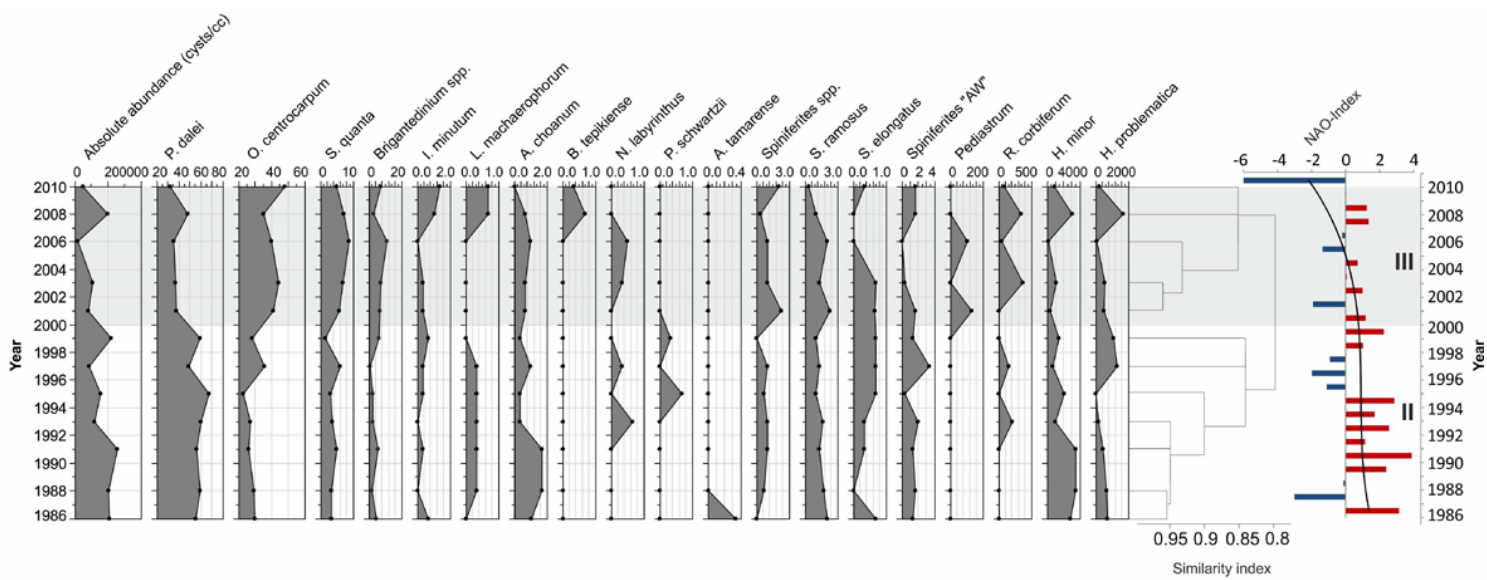

Fig. 5. Cyst assemblages in MC 61-1 and associated groups according to cluster analysis; cyst concentrations and Chlorophycean and Prasinophyceae algae are given in $\mathrm{nb} \mathrm{cc}^{-1}$, relative dinocyst abundances are given in \%; the NAO index is shown to the right (Hurrell, 1995).

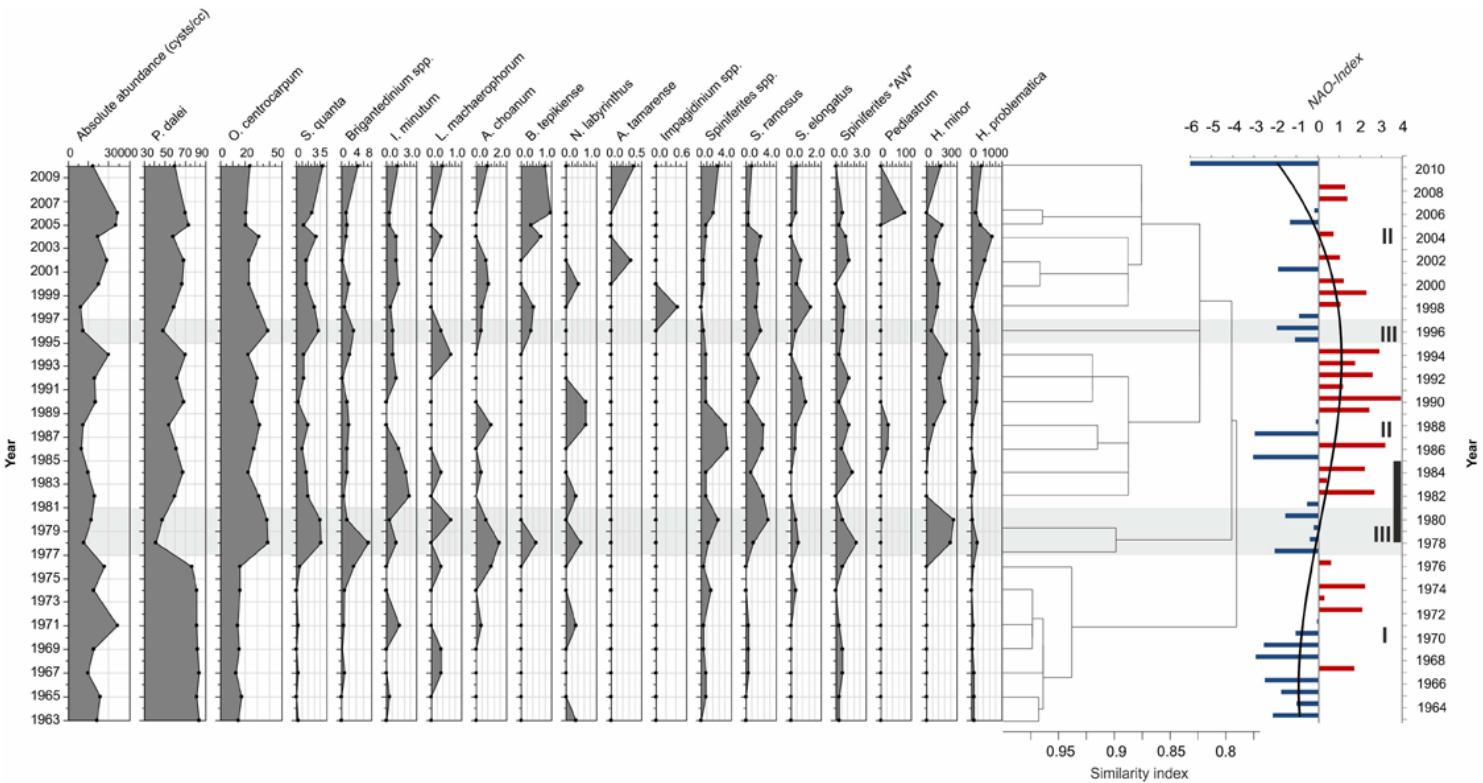

Fig. 6. Cyst assemblages in MC 99-1 and associated groups according to cluster analysis; cyst concentrations and Chlorophycean and Prasinophyceae algae are given in $\mathrm{nb} \mathrm{cc}^{-1}$, relative dinocyst abundances are given in \%; the NAO index is shown to the right (Hurrell, 1995). Black bar on the right axis marks the period (1978-1985) of major hydropower development/implementation in the Orkla river (L'Abée-Lund et al., 2009).

\subsection{Species diversity and temporal succession of assemblages}

Species richness and distribution in the three investigated sediment cores follow the general abundance patterns described by Milzer et al. (2013) from surface sediments in the Trondheimsfjord. Dinocyst assemblages are dominated by $P$. dale $i$ and $O$. centrocarpum. Maximum mean relative abundances of $P$. dalei were found in MC 99-1 in the Seaward Basin (67\%) (Fig. 6) and lowest values in MC 61-1 (50\%) at the fjord entrance (Fig. 5). Cysts of $O$. centrocarpum showed the highest mean relative abundances in MC 61-1 (34\%), followed by MC 99-1 and MC S4-1 with $25 \%$ (Figs. 6 and 7). Cysts of $S$. quanta and Brigantedinium spp. are subordinate in all multi-cores, both averaging $5 \%$ in MC 61-1, ca. $1.7 \%$ in MC 99-1, and $3.6 \%$ (S. quanta) and $5.1 \%$ (Brigantedinium spp.) in MC S4-1. All other species do not exceed $>3 \%$ of the total assemblage.

The recorded species richness and abundances are comparable with the assemblages identified in modern settings of coastal Norway (Grøsfjeld and Harland, 2001; Grøsfjeld et al., 2009) with the exception of $P$. dalei and O. centrocrapum. The reverse dominance of these species in the Trondheimsfjord, with $P$. dalei being the most abundant species, may 


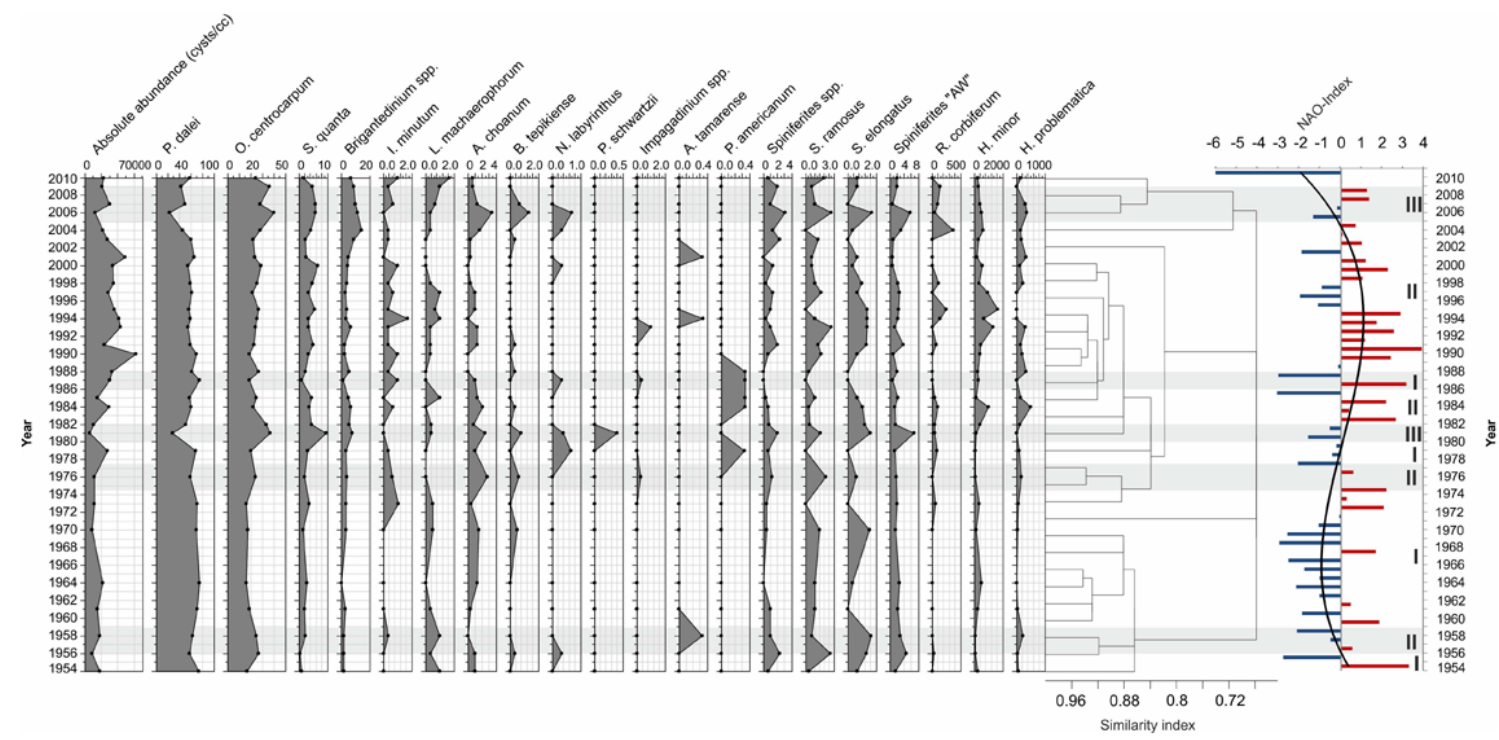

Fig. 7. Cyst assemblages in MC S4-1 and associated groups according to cluster analysis; cyst concentrations and Chlorophycean and Prasinophyceae algae are given in $\mathrm{nb} \mathrm{cm}^{-3}$, relative dinocyst abundances are given in \%; the NAO index is shown to the right (Hurrell, 1995).

be explained by the hydrological differences between the well-stratified, brackish and sheltered fjord and the dynamic coastal environment, as already suggested by Grøsfjeld and Harland (2001). In order to determine precisely changes in the assemblages to the ambient environmental parameters; however, there is a need for further information such as temporal variations in grain size, total organic carbon or amounts of nutrients, which are not available yet.

The cyst assemblages of the three multi-cores show a high degree of temporal and spatial similarity. This is particularly evident in the results of the cluster analysis with similarity indices $>0.7$. The classification of the downcore variabilities by CA mainly relies on the varying relative abundances of the dominant and the subordinate species $P$. dalei, O. centrocarpum, S. quanta and Brigantedinium spp. Statistical analysis with reduced weight on the dominant taxa using log-ratio, exclusion of the dominant species, or based on raw counts or concentration values, did not allow for a statistically based distinction of the samples and thus association with ecological or environmental parameters. Based on CA of the relative cyst abundances we, however, identified three main groups constituting the temporal and spatial organization of the combined data set of cyst assemblages. Cluster analysis performed on the cyst assemblages of the single multi-core assemblages confirms the temporal distribution of the three groups defined by the CA.

Group I is mainly represented in the 1960s and 1970s and therefore only grasped in the MC 99-1 sedimentary archives in the Seaward Basin and MC S4-1 at the fjord head (Fig. 4). This group is characterized by a strong dominance of $P$. dale $i$ (60-80\%) over $O$. centrocarpum (lowest recorded abundance within all three cores) (Figs. 6 and 7). All other taxa, mainly represented by Spiniferites spp., S. ramosus, S. elongatus and Spiniferites "AW" as well as A. choanum and $S$. quanta, generally add up to $<3 \%$ with very low variability.

Group II, mostly represented from around 1980-1982, is characterized by slightly decreased abundances of $P$. dalei (48-75\%), and, in turn, increased occurrences of $O$. centrocarpum (19-35\%), S. quanta (0.3-7\%), Brigantedinium spp. (0.3-9\%), as well as generally minor higher occurrence and variability of all other taxa (Fig. 4).

Group III is temporally distributed during "transitional periods" between groups I and II. This group is characterized by lowest relative abundances of $P$. dalei and highest occurrences of most other taxa (Fig. 4) and explains most of the dinocyst spectra in all three cores during relatively short time intervals of up to $4 \mathrm{yr}$ during the 70 s to 80 s transition, as well as throughout the final part of the records from ca. 2004 (2000 in MC 61-1) (Figs. 5-7).

According to the core chronologies the resolution of the multi-cores is ca. $2 \mathrm{yr} \mathrm{cm}^{-1}$. The chronological framework of the studied cores is related to the classical statistical counting error increasing downcore with a maximum deviation of $5 \mathrm{yr}$ (in MC S4-1). Inconsistencies in the order of 2-3 yr in the timing of group changes between the three sediment cores may thus be partly explained by the sampling strategy $(1 \mathrm{~cm}$-thick homogenized samples) and fall within the error range of dating (higher in the bottom parts of the sediment cores). Still, there are a few single samples or series of samples which fail to follow this general scheme, pointing either to some limitation in the statistical ordination of the data sets, or to local hydrological-sedimentological settings causing irregularities in cyst abundances and diversity. Cyst assemblages in MC 61-1 are largely affected by the adjoining 
Norwegian Sea causing relatively enhanced species richness, and creating environmental conditions which are relatively different from those affecting the other core locations. The dinocyst distribution in MC 99-1 is generally organized according to the main grouping. Annual and/or biannual periods of relatively enhanced species variability and diversity refer to group III and occur from 1977 to 1980 and around 1996 (Fig. 6). The classification of the cyst assemblage in core MC S4-1 (Fig. 7) displays a series of annual to bi-annual shifts from group I to group III throughout the 70 s to $80 \mathrm{~s}$ transition as a result of minor changes in dinocyst abundance in the years 1976, 1981 and 1987.

The three groups and their temporal succession are associated with distinct environmental conditions and potentially with the history of development policies in the Trondheim area in the 70s and the 80s, and their related impact on the physico-chemical structure and trophic state of the surface waters.

Investigations in southern Norwegian fjords showed that high amounts of nutrients related to industrial activity and effluents caused an increase in the cyst concentration and abundance of heterotrophic species such as L. machaerophorum and, in turn, a sharp decrease in the contribution of $P$. dalei (Sætre et al., 1997; Dale et al., 1999a). Regulations to reduce the impact of agricultural and industrial activities on the quality of Trondheimsfjord waters were successfully applied around 1980 (Tangen and Arff, 2003). If eutrophication were one of the important driving forces for the dinocyst production in the Trondheimsfjord during the past $50 \mathrm{yr}$, this would result in a temporal pattern of the assemblage distribution opposite to the one observed in the present study (Figs. 6 and 7). We therefore conclude, with the exception of a potential minor impact due to the implementation of hydropower plants, that dinocyst abundance patterns over the last $50 \mathrm{yr}$ were essentially controlled by natural environmental/climatological changes.

The period from the 1960s and the 70s which is associated with group I is characterized by a long-term negative NAO phase, with lower than normal river discharges into the Seaward Basin and the Middle Fjord, as well as relatively high mean SSSs and low mean SSTs (Fig. 2). This pattern was interrupted during the early 70 s by a short interval of positive NAO pattern and respective changes in the physico-chemical characteristics of the surface waters. The high representation of the cyst assemblages typical of group I within cores MC 99-1 and MC S4-1 during the 60s and 70 s is supposed to result from increased continental influence in the inner fjord basins which may intensify changes in the sea-surface parameters associated with the NAO phases. Low amounts of river discharges from the hinterland and thus reduced supply of nutrients into the fjord impede the production of phytoplankton prey for heterotrophic species from spring to autumn, and might explain the scarcity of taxa such as $S$. quanta, Brigantedinium spp., I. minutum and $L$. machaerophorum in group I (Figs. 6 and 7).
After 1980 the period is mainly represented by group II. During this period the NAO changed to a long-term positive oscillation pattern resulting in generally higher SSTs, higher than normal mean river discharges, and lower SSSs (Fig. 2). The temporal distribution of the cyst assemblages referred to group II within the three studied cores is, however, less straightforward and homogenous than group I before the 1980s (Figs. 4-7). This may relate to ill-defined NAO conditions after 1996 leading to rapid fluctuations in SSTs, river discharges and SSSs. Anyhow, regarding the general homogeneity of the assemblages, even minor deviations in the species abundance may lead to the determination of the samples into another group and cannot necessarily be explained by measurable changing environmental conditions. Still, we assume that the generally higher contributions of heterotrophic species and cysts with a preference for mesotrophic conditions within all cores after 1980 are indicative of enhanced phytoplankton production related to increased nutrient load from rivers and internal mixing. Group III associated with the largest species richness generally occurred throughout the 70 s to 80 s transition as well as after 2000 , both periods during which the NAO shifted from one long-term mode to another. Its absence from the most recent part of core MC 99-1 (Fig. 6) might be related to the regulation of river inputs into the Seaward Basin due to the implementation of hydropower plants in the early to mid 1980s (Orkla river; L'Abée-Lund et al., 2009). The artificially modified river discharges might account for the heterogeneous patterns of discharge anomalies between the rivers Orkla, Gaula and Nidelva (low discharges) and the other major tributaries to the Trondheimsfjord (high discharges) (Fig. 2). Alternatively, in the central Seaward Basin changes in the surface water characteristics due to enhanced riverine discharge may be diminished by mixing with the incoming tidal currents and the ambient fjord surface water.

Calculated correlation coefficients between the NAO index and the dinocyst assemblages, however, yield low values $\left(R^{2}<0.5\right)$. These low values are likely to be explained by the complex and rather indirect link between the NAO and the cyst assemblages, translated by river discharges and the water column stability. Additionally, as previously mentioned, downcore changes in cyst assemblages are minor and may therefore be statistically not significant enough when compared with long- and short-term high-amplitude changes in the NAO index.

\subsection{Quantitative reconstruction of SSTs, SSSs and PP}

The MAT applied for the reconstruction of SSTs and SSSs relates to the 5 best analogues for every multi-core sample, with distances below the statistical thresholds for all cores. Tests for autocorrelation due to the analogues' sites did not reveal significant changes in the reconstructions, yielding max. $\Delta R^{2}=0.2$ and a correspondingly increased RMSEP. Reconstructed temperatures and salinities accordingly yield 


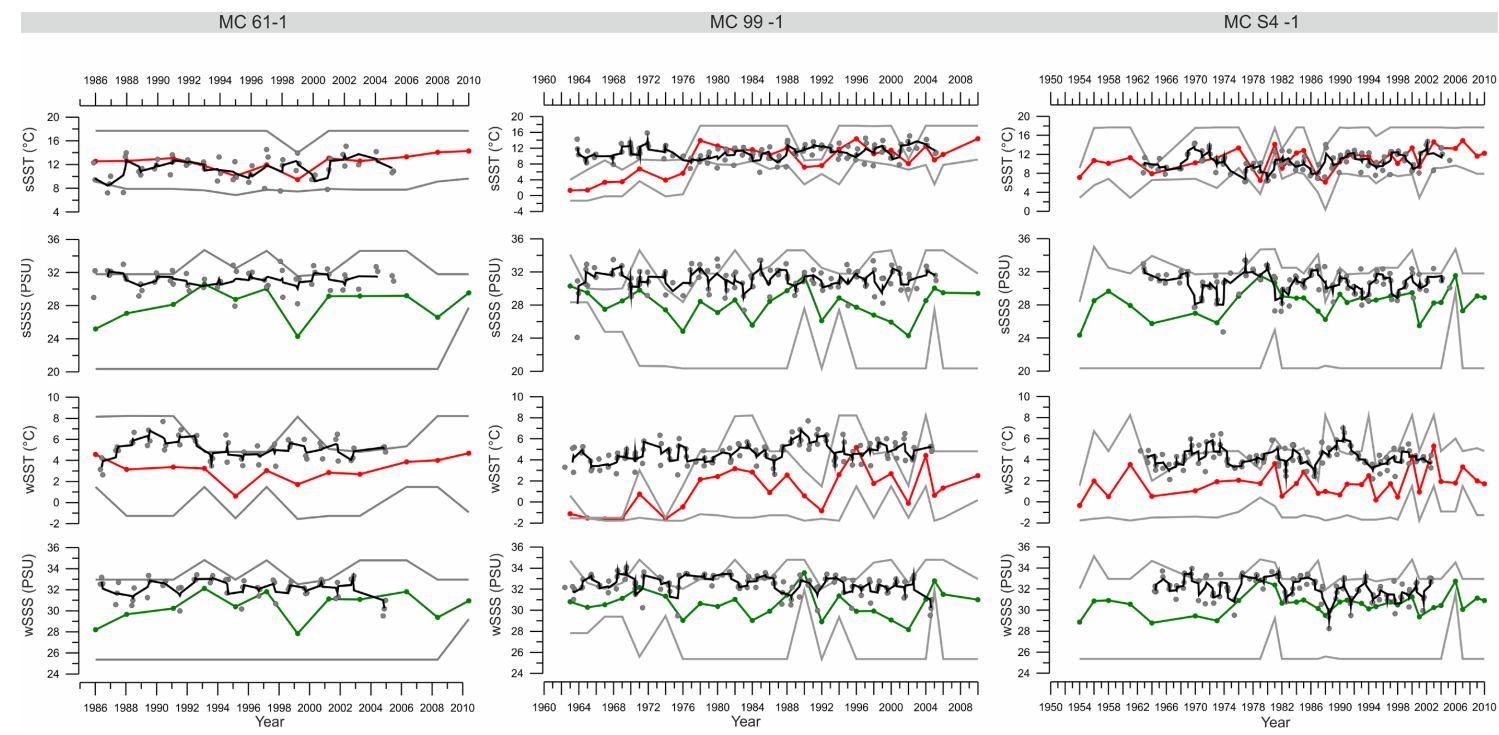

Fig. 8. Winter and summer SST and SSS reconstructions based on cyst assemblages at every core site; red line: SST; green: SSS; grey surrounding lines: minimum and maximum estimates for each reconstructed value calculated from the set of the 5 selected analogues; grey dots: instrumental temperatures and salinities measured at the respective mooring station, Røberg for MC 61-1 and MC 99-1 and Ytterøy for MC S4-1; black lines are the three-point running average of the instrumental temperatures and salinities.

a maximum difference of $\pm 2{ }^{\circ} \mathrm{C} / 3$ PSU compared with the complete data set. Hence, although we cannot exclude the risk of spatial and/or temporal autocorrelation in the reconstructed data, our estimated values are relatively robust.

The reconstructed hydrological values in all cores maintain the overall seasonal temperature and salinity structure of the surface water as recorded at the respective mooring stations (Røberg for MC 61-1 and MC 99-1, and Ytterøy for MC S4-1) with low SSTs and higher SSSs in winter, and high SSTs and slightly lower SSSs in summer. Generally, all estimated minimum values of summer and winter SSTs and SSSs as well as PP are significantly underestimated in all cores compared with the instrumental measurements at the respective mooring station (Wilcoxon test: $p<0.05$ ). In MC 61-1 winter and summer SST and max. SST range between $3.2^{\circ} \mathrm{C}$ and $6.6^{\circ} \mathrm{C}$, and $12.4^{\circ} \mathrm{C}$ and $17.4^{\circ} \mathrm{C}$, respectively. Summer salinity varies from $28.1 \mathrm{PSU}$ (SSS) to 32.8 PSU (max. SSS), and winter SSS and max. SSS from 30.4 PSU to 33.5 PSU. Winter SST and max. SST in MC 991 yield 1.1 and $3.7^{\circ} \mathrm{C}$ (Table 3, Fig. 8) and a summer SST and max. SST $9.0^{\circ} \mathrm{C}$ and $13.7^{\circ} \mathrm{C}$, respectively. Summer SSS and max. SSS vary between 28.1 and 32.4 PSU and between 30.6 and 33.5 PSU in winter. In MC S4-1 in the Middle Fjord SST and max. SST range from $1.8^{\circ} \mathrm{C}$ to $5.1{ }^{\circ} \mathrm{C}$ in winter and from $11.0^{\circ} \mathrm{C}$ to $16.2^{\circ} \mathrm{C}$ in summer. SSS and max. SSS yield 28.3 PSU and 32.4 PSU in summer and 30.6 PSU and 33.3 PSU in winter, respectively.

Regardless of the site-specific chronological extent and time resolution of the downcore records, reconstructed seasurface abiotic parameters in terms of maximum and highest probability values are in relatively good agreement with the modern instrumental data and general temporal variability (Table 3, Fig. 8). However, the correspondence of the estimated values to the instrumental measurements varies with the core location, the reconstructed sea-surface parameter and the reference sites identified. At the fjord entrance (MC 61-1) the best agreement with the instrumental measurements in the central Seaward Basin (Røberg) is achieved by the reconstructions of the the summer SSTs and winter max. SSTs (Table 3, Fig. 8). In MC 99-1 in the Seaward Basin estimated winter max. SSTs and summer SSTs and max. SSS are considered as significantly similar $(p>0.05)$ to the instrumental measurements. Dinocyst-based reconstructions from the Middle Fjord reveal significant correspondence with the instrumentally measured temperatures in Ytterøy only for the summer SSTs, with mean values of $11.0^{\circ} \mathrm{C}$ and $10.4^{\circ} \mathrm{C}$ and winter max. SSTs with $4.2^{\circ} \mathrm{C}$ and $5.1^{\circ} \mathrm{C}$, respectively.

Still, despite the relative good fit between the estimated values and the instrumental measurements, there are several aspects which may cause the observed deviations, and/or technical biases which have to be carefully considered when interpreting the data. The hydrographic data which constitute our reference modern data average the environmental information over several decades. The dinocyst spectra may include populations representative of several years to a millennium depending on the sedimentation rate and the biological mixing depth at the sampling sites (de Vernal et al., 2001). The reference data sets may therefore not be strictly representative of the modern environmental setting in the Trondheimsfjord regarding the resolution of the multicores. Furthermore, the parameters reconstructed, i.e. winter and summer SSTs, are not necessarily representative of 
Table 3. Descriptive statistics (mean, range, minimum and maximum values) of hydrographic characteristics measured at each mooring station at $10 \mathrm{~m}$ water depths and of MAT reconstructions of winter and summer SSTs and SSSs (confidence level 95\%); instrumentally measured SSTs and SSSs are denoted by the name of the mooring stations, Røberg and Ytterøy; estimated SSTs and SSSs including min. and max. values are marked by the core names MC 61-1, MC 99-1 and MC S4-1. Standard errors (Std.e.) for the mean values are given in brackets.

\begin{tabular}{|c|c|c|c|c|c|c|c|c|}
\hline \multicolumn{9}{|l|}{ MC 61-1 } \\
\hline Summer & Røberg & SST & $\min . \mathrm{SST}$ & $\max . \mathrm{SST}$ & Røberg & SSS & min. SSS & $\max . \mathrm{SSS}$ \\
\hline Mean (Std. error) & $11.0(0.2)$ & $12.4(0.4)$ & $8.1(0.2)$ & $17.4(0.3)$ & $31.1(0.1)$ & $28.1(0.6)$ & $21.0(0.6)$ & $32.8(0.4)$ \\
\hline Range & 10 & 4.8 & 2.8 & 3.7 & 9.5 & 6.3 & 7.4 & 3.2 \\
\hline Minimum & 5.9 & 9.5 & 6.8 & 14.0 & 24.1 & 24.3 & 20.4 & 31.6 \\
\hline Maximum & 15.9 & 14.3 & 9.6 & 17.7 & 33.6 & 30.6 & 27.8 & 34.7 \\
\hline Winter & Røberg & SST & $\min . \mathrm{SST}$ & $\max . \mathrm{SST}$ & Røberg & SSS & min. SSS & $\max . \mathrm{SSS}$ \\
\hline Mean (Std. error) & $4.7(0.1)$ & $3.2(0.3)$ & $-0.1(0.4)$ & $6.6(0.5)$ & $32.5(0.1)$ & $30.4(0.7)$ & $25.7(0.3)$ & $33.5(0.3)$ \\
\hline Range & 5.1 & 4.1 & 3.0 & 3.4 & 4.6 & 4.3 & 3.9 & 2.3 \\
\hline Minimum & 2.6 & 0.6 & -1.6 & 4.8 & 29.5 & 27.8 & 25.4 & 32.5 \\
\hline Maximum & 7.7 & 4.7 & 1.5 & 8.2 & 34.1 & 32.1 & 29.2 & 34.8 \\
\hline \multicolumn{9}{|l|}{ MC 99-1 } \\
\hline Summer & Røberg & SST & $\min . \mathrm{SST}$ & $\max . \mathrm{SST}$ & Røberg & SSS & $\min . \mathrm{SSS}$ & $\max . \mathrm{SSS}$ \\
\hline Mean (Std. error) & $11.0(0.2)$ & $9.0(0.8)$ & $5.0(0.8)$ & $13.7(1.0)$ & $31.1(0.1)$ & $28.1(0.4)$ & $22.3(0.6)$ & $32.4(0.4)$ \\
\hline Range & 10 & 13.1 & 10.4 & 13.7 & 9.5 & 7.2 & 8.0 & 6.3 \\
\hline Minimum & 5.9 & 1.3 & -1.3 & 4.0 & 24.1 & 24.3 & 20.4 & 28.4 \\
\hline Maximum & 15.9 & 14.4 & 9.1 & 17.7 & 33.6 & 31.5 & 28.3 & 34.6 \\
\hline Winter & Røberg & SST & $\min . \mathrm{SST}$ & $\max . \mathrm{SST}$ & Røberg & SSS & $\min . \mathrm{SSS}$ & $\max . \mathrm{SSS}$ \\
\hline Mean (Std. error) & $4.7(0.1)$ & $1.1(0.4)$ & $-1.1(0.2)$ & $3.7(0.7)$ & $32.5(0.1)$ & $30.6(0.3)$ & $26.8(0.5)$ & $33.5(0.2)$ \\
\hline Range & 5.1 & 6.8 & 3.3 & 9.7 & 4.6 & 5.4 & 6.6 & 2.8 \\
\hline Minimum & 2.6 & -1.6 & -1.8 & -1.5 & 29.5 & 28.2 & 25.4 & 32.0 \\
\hline Maximum & 7.7 & 5.2 & 1.5 & 8.2 & 34.1 & 33.6 & 31.9 & 34.8 \\
\hline \multicolumn{9}{|l|}{ MC S4-1 } \\
\hline Summer & Ytterøy & SST & $\min . \mathrm{SST}$ & $\max . \mathrm{SST}$ & Ytterøy & SSS & $\min$. SSS & $\max . \mathrm{SSS}$ \\
\hline Mean (Std. error) & $10.4(0.2)$ & $11.0(0.4)$ & $6.8(0.5)$ & $16.2(0.6)$ & $30.6(0.1)$ & $28.3(0.3)$ & $20.8(0.3)$ & $32.4(0.3)$ \\
\hline Range & 8.5 & 8.7 & 12.1 & 8.6 & 8.7 & 7.2 & 9.2 & 6.6 \\
\hline Minimum & 6.2 & 6.2 & 0.3 & 9.1 & 24.7 & 24.4 & 20.4 & 28.4 \\
\hline Maximum & 14.7 & 14.9 & 12.4 & 17.7 & 33.4 & 31.5 & 29.6 & 35.0 \\
\hline Winter & Ytterøy & SST & $\min . \mathrm{SST}$ & $\max . \mathrm{SST}$ & Ytterøy & SSS & $\min . \mathrm{SSS}$ & $\max . \mathrm{SSS}$ \\
\hline Mean (Std. error) & $4.2(0.1)$ & $1.8(0.2)$ & $-1.1(0.2)$ & $5.1(0.3)$ & $32.0(0.1)$ & $30.6(0.2)$ & $25.7(0.2)$ & $33.3(0.2)$ \\
\hline Range & 4.9 & 5.6 & 3.3 & 6.7 & 5.7 & 4.1 & 6.2 & 3.2 \\
\hline Minimum & 2.1 & -0.3 & -1.8 & 1.5 & 28.2 & 28.8 & 25.4 & 31.9 \\
\hline Maximum & 7 & 5.3 & 1.5 & 8.2 & 34 & 32.8 & 31.6 & 35.1 \\
\hline
\end{tabular}

the dinocyst blooming seasons, but the ranges given between two extrema (minimal/ maximal values within a year) is ecologically meaningful regarding the phytoplankton dynamics. Still, winter SSTs estimated by MAT are calculated with regard to the yearly lowermost values observed at the analogues core sites and may account for the generally large underestimation of winter SSTs (de Vernal et al., 2000, 2005).

Qualitatively, most deviations from the instrumental data may be explained by the poor species richness. The dominating species $P$. dalei is assumed to thrive best in regions characterized by cold and low saline surface layers close to seaice margins. $O$. centrocarpum is considered as a cosmopoli$\tan$ species with a strong preference for warm and saline wa- ters and a strong ability to adapt to rapid changes (e.g. Marret and Zonneveld, 2003; Zonneveld et al., 2013). The effect of changing abundances can be essentially observed in reconstructed SSTs in MC 99-1 before 1976 when $P$. dalei dominated the assemblages by up to $80 \%$. The reconstructed summer and winter SSTs reveal very low values (mean around $4{ }^{\circ} \mathrm{C}$ and $-2{ }^{\circ} \mathrm{C}$ in summer and winter, respectively) from 1960 to 1976 . This is clearly at odds with the instrumental measurements which show only minor changes in the measured summer and winter temperatures around $10^{\circ} \mathrm{C}$ and $4{ }^{\circ} \mathrm{C}$, respectively. Furthermore, most species in the Trondheimsfjord tolerate large temperature and salinity changes as typical for coastal and fjord environments and none of the 


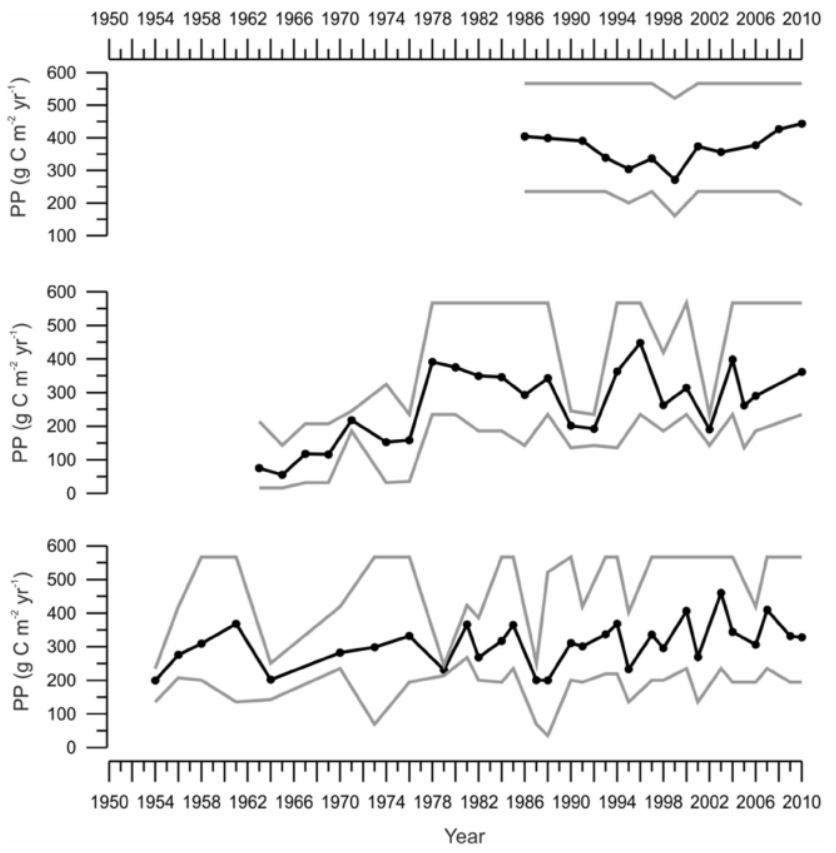

Fig. 9. Reconstructed primary productivity $\left(\mathrm{g} \mathrm{C} \mathrm{m}^{-2} \mathrm{yr}^{-1}\right)$ at every core site (black lines); grey surrounding lines: minimum and maximum estimates for each reconstructed value calculated from the set of the 5 selected analogues.

species follows the surface temperature and salinity variability measured in the fjord (Fig. 2). Based on our previous observations of changes in the cyst assemblages linked to the ambient environmental parameters (see Sect. 4.2) we assume that cyst production in the Trondheimsfjord during the last $50 \mathrm{yr}$ is to a high extent controlled by the nutrient availability linked to internal mixing and river discharges as well as dynamically induced stress, rather than empirically and solely SSTs and SSSs.

The reconstructed mean PP values are lowest at MC 99$1\left(260 \mathrm{~g} \mathrm{C} \mathrm{m}^{-2} \mathrm{yr}^{-1}\right)$ and highest at MC $61-1\left(370 \mathrm{~g} \mathrm{C} \mathrm{m}^{-2}\right.$ $\mathrm{yr}^{-1}$ ) (Table 4, Fig. 9). The range between minimum and maximum estimated PP for a given core location is significantly higher in the Seaward Basin and Middle Fjord (ca. $250-400 \mathrm{~g} \mathrm{C} \mathrm{m}^{-2} \mathrm{yr}^{-1}$ ) than at the fjord entrance (MC 61-1: $70 \mathrm{~g} \mathrm{C} \mathrm{m}^{-2} \mathrm{yr}^{-1}$ ). In the absence of published data sets on annual rates of primary productivity in the Trondheimsfjord, a proper comparison of estimated vs. measured PP values is not possible. Chlorophyll distributions extracted from moderate resolution images of the MODIS spectroradiometer for the 2002-2005 period translate into an annual primary productivity of $200-300 \mathrm{~g} \mathrm{C} \mathrm{m}^{-2} \mathrm{yr}^{-1}$ along the Norwegian coast (http://daac.gsfc.nasa.gov). This is twice the rate reported by Erga et al. (2005) and Aure et al. (2007) for Norwegian fjords and coastal waters, but corresponds to measured PP in local Scandinavian fjords ranging between 95 and $241 \mathrm{~g} \mathrm{C} \mathrm{m}^{-2} \mathrm{yr}^{-1}$ (Grundle et al., 2009 and references therein) as well as to the $150-300 \mathrm{~g} \mathrm{C} \mathrm{m}^{-2} \mathrm{yr}^{-1} \mathrm{PP}$ range re-
Table 4. Descriptive statistics of MAT reconstructions of annual primary productivity (confidence level of $95 \%$ ); standard errors for the mean values (Std.e.) are given in brackets.

\begin{tabular}{lccc}
\hline MC 61-1 & PP & min. & $\max$. \\
\hline Mean (Std. error) & $368.4(14.4)$ & $222.6(7.0)$ & $563.3(3.8)$ \\
Range & 172.3 & 74.3 & 45.4 \\
Min. & 271.0 & 160.7 & 521.6 \\
Max. & 443.3 & 235.1 & 567.0 \\
MC 99-1 & PP & min. & $\operatorname{max.}$ \\
Mean (Std. error) & $261.3(22.8)$ & $148.8(16.4)$ & $420.1(34.7)$ \\
Range & 392.9 & 219.0 & 423.9 \\
Min. & 55.3 & 16.1 & 143.1 \\
Max. & 448.1 & 235.1 & 567.0 \\
MC S4-1 & PP & min. & $\max$. \\
Mean (Std. error) & $308.3(12.0)$ & $184.2(9.9)$ & $486.6(21.2)$ \\
Range & 260.6 & 232.7 & 332.0 \\
Min. & 199.3 & 35.3 & 235.1 \\
Max. & 460.0 & 268.0 & 567.0 \\
\hline
\end{tabular}

ported by the UNEP Regional Seas Programme for coastal waters off Norway (Sherman and Hempel, 2008). Furthermore, primary productivity in coastal areas collected by MODIS are considered to be slightly overestimated, which accordingly leads to overestimations of the reconstructed PP data (Durantou, 2013, reviewer comment). However, we cannot exclude effects of autocorrelation due to the dynamic link of salinity and primary productivity in the Trondheimsfjord.

Hence, despite the relatively accurate reconstructed values for winter and summer SSTs and SSSs as well as for mean annual PPs we suggest that estimated parameters have to be carefully evaluated with regard to the reference data sets used for the reconstructions, the climatic and environmental fluctuations and associated changes in the cyst assemblages.

\section{Conclusions}

Dinocyst assemblages from three sediment cores in the Trondheimsfjord show a high degree of coherency in terms of temporal succession. Changes in cyst abundances and species diversity essentially reflect decadal-scale changes in NAO pattern and related variability in SSTs, river discharges, SSSs and trophic conditions at the time of cyst production. Significant impact by human activity on the fjord ecological state over the last $50 \mathrm{yr}$ is barely detectable from the investigated micropaleontological successions. Deviations from the NAO-induced pattern of dinocyst assemblage composition between each core site can be mainly explained by local hydrological and topographical features.

Species assemblages in core MC 61-1 at the fjord entrance reveal relatively high species evenness and cyst concentrations. Downcore changes in species distribution are primarily driven by regional-scale variations in the physico-chemical 
characteristics of the NCC linked to the changing continental run-off from southern Scandinavia.

Core site MC 99-1 in the Seaward Basin is located in the flow path of strong tide and bottom water currents, and high river inputs from the local rivers Orkla and Gaula. Both induce inward and seaward displacement of cysts and sediments across the fjord as well as dilution of microfossils by terrigeneous sediments. This explains the lowest recorded mean average cyst concentrations. However, at this stage we cannot explain the poor species evenness and the dominance of $P$. dale $i$ at this location compared with the inner fjord location (MC S4-1).

Cyst assemblages at the most inshore site MC S4-1 reflect the relative influence of marine vs. continental climate and associated changes in the physico-chemical surface water characteristics related to the prevailing NAO phase. The core location is strongly influenced by the river Verdalselva. Associated sediment and nutrient loads on one hand trigger cyst production and on the other hand may cause dilution of any fossil remains by terrigeneous material.

Reconstructed mean and maximum abiotic and biotic seasurface parameters are in relatively good agreement with measured time-series SSTs and SSSs in the Trondheimsfjord as well as with mean annual primary productivity rates from coastal Norway and other Scandinavian fjords. Best estimates are generally achieved for summer SST and SSS. Nevertheless, the poor species evenness and the commonly large tolerance to SST and SSS changes in the dominant and subordinate species may result in estimated values unlike the observed temperature and salinity trend. We therefore suggest that the estimated values of primary productivity reflect best the varying environmental conditions driving the production of cysts. Our pilot study also suggests that the use of MAT transfer functions for the reconstruction of sea-surface parameters at a very high temporal scale such as implemented here (annual to bi-annual over the last ca. $50 \mathrm{yr}$ ) might be hampered by the "modern" analogue reference hydrographic and dinocyst data sets which are often representative of environmental conditions averaged over multi-annual to multicentennial scales.

\section{Supplementary material related to this article is available online at http://www.clim-past.net/10/305/2014/ cp-10-305-2014-supplement.pdf.}

Acknowledgements. This work is a contribution to the CASE initial training network funded by the European Community's 7th Framework Programme FP7 2007/2013, Marie-Curie Actions, under grant agreement no. 238111 (http://caseitn.epoc.ubordeaux1.fr/index.php/home.html). Temperature and salinity data sets from the fjord mooring hydrological stations are provided by the Trondheim Biological Station of the
Norwegian University of Science and Technology. We gratefully acknowledge Bendik Eithun Halgunset from Sør-Trøndelag Fylkeskommune, Viggo Finset from TrønderEnergi Kraft AS, as well as Arne Jørgen Kjøsnes and Eva Klausen from the Norwegian Water Resources and Energy Directorate for their cooperation, helpful suggestions and data access. Anne de Vernal (GEOTOP, UQAM) is gratefully acknowledged for her support, helpful suggestions and reference data. Ultimately, we would like to thank R. Telford (UIB, Norway) for critical comments and helpful discussions concerning statistical data treatment and transfer functions.

Edited by: D.-D. Rousseau

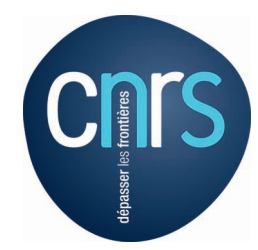

The publication of this article is financed by CNRS-INSU.

\section{References}

Appleby, P. G.: Chronostratigraphic techniques in recent sediments, in Tracking environmental change using lake sediments. Volume 1: Basin analysis, coring, and chronological techniques., edited by: Last, W. M. and Smol, J. P., p. 2001, Kluwer Academic Publishers, Dordrecht, the Netherlands, 2001.

Aure, J., Strand, Ø., Erga, S., and Strohmeier, T.: Primary production enhancement by artificial upwelling in a western Norwegian fjord, Mar. Ecol. Prog. Ser., 352, 39-52, doi:10.3354/meps07139, 2007.

Bayon, G., Henderson, G. M., and Bohn, M.: U-Th stratigraphy of a cold seep carbonate crust, Chem. Geol., 2, 47-56, 2009.

Bigler, C. and Wunder, J.: Statistische Datenanalyse mit R?: Eine Einführung für Umweltwissenschaftler, Gebirgswaldökologie (D-FOWI), ETH Zürich, Version 1.0, 1-39, 2003.

Birks, H. J. B.: Quantitative palaeoenvironmental reconstructions, Stat. Model. Quat. Sci. Data. Tech. Guid. 5, edited by: Maddy, D. and Brew, J. S., Quat. Res. Assoc. Cambridge, 5, 161-254, 1995.

Blindheim, J., Borovkov, V., Hansen, B., Malmberg, S.-A., Turrell, W. R., and Østerhus, S.: Upper layer cooling and freshening in the Norwegian Sea in relation to atmospheric forcing, Deep Sea Res. Part I, 47, 655-680, doi:10.1016/S0967-0637(99)00070-9, 2000.

Blume, H. P., Brümmer, G., Horn, R., Kretzschmar, R., Kandeler, E., Kögel-Knabner, I., Stahr, K., and Wilke, B. M.: Scheffer/Schachtschabel: Lehrbuch der Bodenkunde, Springer Spektrum, 2009.

Bøe, R., Rise, L., Blikra, L. H., Longva, O., and Eide, A.: Holocene mass-movement processes in Trondheimsfjorden, Central Norway, Norw. J. Geol., 83, 3-22, 2003.

Dale, B.: Cyst formation, sedimentation and preservation: factors affecting dinoflagellate assemblages in recent sediments from Trondheimsfjord, Norway, Rev. Palaeobot. Palynol., 22, 39-60, 1976. 
Dale, B.: Marine dinoflagellate cysts as indicators of eutrophication and industrial pollution: a discussion., Sci. Total Environ., 264, 235-240, 2001.

Dale, B., Thorsen, T. A., and Fjellsa, A.: Dinoflagellate cysts as indicators of cultural eutrophication in the Oslofjord, Norway, Estuar. Coast. Shelf S., 48, 371-382, doi:10.1006/ecss.1999.0427, 1999a.

Dale, T., Rey, F., and Heimdal, B. R.: Seasonal development of phytoplankton at a high latitude oceanic site, Sarsia, 84, 419-435, 1999b.

Dale, B., Dale, A. L., and Jansen, J. H. F.: Dinoflagellate cysts as environmental indicators in surface sediments from the Congo deep-sea fan and adjacent regions, Palaeogeogr. Palaeocl., 185, 309-338, 2002.

De Vernal, A. and Marret, F.: Organic-Walled Dinoflagellate Cysts: Tracers of Sea-Surface Conditions, Mar. Geol., 1, 371-408, doi:10.1016/S1572-5480(07)01014-7, 2007.

De Vernal, A., Rochon, A., Hillaire-Marcel, C., Turon, J. L., and Guiot, J.: Quantitative reconstruction of sea-surface conditions, seasonal extent of sea-ice cover and meltwater discharges in high latitude marine environments from dinoflagellate cyst assemblages, Nato. Asi. Ser., I12, 611-621, 1993.

De Vernal, A., Henry, M., and Bilodeau, G.: Techniques de Préparation et d'Analyse en Micropaleontologie, Le Cah. du GEOTOP, 3, Université du Québec à Montréal, Canada, 1996.

De Vernal, A., Hillaire-Marcel, C., Turon, J.-L., and Matthiessen, J.: Reconstruction of sea-surface temperature, salinity, and seaice cover in the northern North Atlantic during the last glacial maximum based on dinocyst assemblages, Can. J. Earth Sci., 37, 725-750, doi:10.1139/e99-091, 2000.

De Vernal, A., Henry, M., Matthiessen, J., Mudie, P. J., Rochon, A., Boessenkool, K. P., Eynaud, F., Grøsfjeld, K., Guiot, J., Hamel, D., Harland, R., Head, M. J., Kunz-Pirrung, M., Levac, E., Loucheur, V., Peyron, O., Pospelova, V., Radi, T., Turon, J.L., and Voronina, E.: Dinoflagellate cyst assemblages as tracers of sea-surface conditions in the northern North Atlantic, Arctic and sub-Arctic seas: the new $n=677$ data base and its application for quantitative palaeoceanographic reconstruction, J. Quaternary S., 16, 681-698, doi:10.1002/jqs.659, 2001.

De Vernal, A., Eynaud, F., Henry, M., Hillaire-Marcel, C., Londeix, L., Mangin, S., Matthiessen, J., Marret, F., Radi, T., Rochon, A., Solignac, S., and Turon, J.-L.: Reconstruction of seasurface conditions at middle to high latitudes of the Northern Hemisphere during the Last Glacial Maximum (LGM) based on dinoflagellate cyst assemblages, Quaternary Sci. Rev., 24, 897924, doi:10.1016/j.quascirev.2004.06.014, 2005.

Devillers, R. and de Vernal, A.: Distribution of dinoflagellate cysts in surface sediments of the northern North Atlantic in relation to nutrient content and productivity in surface waters, Mar. Geol., 166, 103-124, doi:10.1016/S0025-3227(00)00007-4, 2000.

Durantou, L., Rochon, A., Ledu, D., Massé, G., Schmidt, S., and Babin, M.: Quantitative reconstruction of sea-surface conditions over the last $150 \mathrm{yr}$ in the Beaufort Sea based on dinoflagellate cyst assemblages: the role of large-scale atmospheric circulation patterns, Biogeosciences, 9, 5391-5406, doi:10.5194/bg-9-5391$2012,2012$.
Ellingsen, I. H.: Internal tides and the spread of river plumes in the Trondheimfjord, 1-174 pp., Norwegian University of Science and Technology (NTNU), Trondheim, 2004.

Erga, S. R., Aursland, K., Frette, Ø., Hamre, B., Lotsberg, J. K., Stamnes, J. J., Aure, J., Rey, F., and Stamnes, K.: UV transmission in Norwegian marine waters: controlling factors and possible effects on primary production and vertical distribution of phytoplankton, Mar Ecol. Prog. Ser., 305, 79-100, doi:10.3354/meps305079, 2005.

Grøsfjeld, K. and Harland, R.: Distribution of modern dinoflagellate cysts from inshore areas along the coast of southern Norway, J. Quaternary Sci., 16, 651-659, doi:10.1002/jqs.653, 2001.

Grøsfjeld, K., Harland, R., and Howe, J.: Dinoflagellate cyst assemblages inshore and offshore Svalbard reflecting their modern hydrography and climate, Norw. J. Geol., 89, 121-134, 2009.

Grundle, D. S., Timothy, D. A., and Varela, D. E.: Variations of phytoplankton productivity and biomass over an annual cycle in Saanich Inlet, a British Columbia fjord, Cont. Shelf Res., 29, 2257-2269, doi:10.1016/j.csr.2009.08.013, 2009.

Guiot, J. and de Vernal, A.: Transfer Functions?: Methods for Quantitative Paleoceanography Based on Microfossils, HillaireMarcel, C., Vernal, A. Proxies Late Cenozoic Paleoceanogr. Elsevier, 1, 523-563, doi:10.1016/S1572-5480(07)01018-4, 2007.

Hammer, Ø., Harper, D. A. T., and Ryan, P. D.: Paleontological Statistics Software, Paleontol. Electron., 4, 0-9, available at: http://www.folk.uio.no/ohammer/past/ (last access: April 2012), Version 2.15, 2001.

Harland, R.: Distribution maps of recent dinoflagellate cysts in bottom sediments from the North Atlantic Ocean and adjacent seas, Paleontology, 26, 321-387, 1983.

Harland, R., Nordberg, K. ,and Filipsson, H. L.: A high-resolution dinoflagellate cyst record from latest Holocene sediments in Koljö Fjord, Sweden, Rev. Palaeobot. Palynol., 128, 119-141, doi:10.1016/S0034-6667(03)00116-7, 2004.

Harland, R., Nordberg, K., and Filipsson, H. L.: Dinoflagellate cysts and hydrographical change in Gullmar Fjord, west coast of Sweden, Sci. Total Environ., 355, 204-231, doi:10.1016/j.scitotenv.2005.02.030, 2006.

Head, M. J., Harland, R., and Matthiessen, J.: Cold marine indicators of the late Quaternary: The new dinoflagellate cyst genus Islandinium and related morphotypes, J. Quaternary Sci., 16, 621636, doi:10.1002/jqs.657, 2001.

Head, M. J., Lewis, J., and de Vernal, A.: The cyst of the calcareous dinoflagellate Scrippsiella trifida; resolving the fossil record of its organic wall with that of Alexandrium tamarense, J. Paleontol., 80, 1-18, 2006.

Howe, J. A., Austin, W. E. N., Forwick, M., Paetzel, M., Harland, R. and Cage, A. G.: Fjord systems and archives: a review, in: Fjord Systems and Archives, edited by: Howe, J. A., Austin, W. E. N., Forwick, M., and Paetzel, M., Geological Society, London, Special Publications, 344, 207-223, 2010.

Hurrell, J. W.: Decadal trends in the North Atlantic Oscillation: Regional Temperatures and precipitation, Science, 269, 676-679, 1995. 
Hurrell, J. W. and van Loon, H.: Decadal variations in climate associated with the North Atlantic Oscillation, in: Climatic Change, 36, 301-326, Kluwer Academic Publishers, Dordrecht, the Netherlands, 1997.

Imbrie, J. and Kipp, N. G.: A new micropaleontological method for quantitative paleoclimatology: Application to a late Pleistocene Caribbean core, edited by: Turekian, K. K., Late Cenozoic Glacial Ages 71-181; Yale Univ. Press. New Haven, CT, 1971.

Jacobson, P.: Physical oceanography of the Trondheimsfjord, Geophys. Astro. Fluid, 26, 3-26, 1983.

Kirchner, G.: ${ }^{210} \mathrm{~Pb}$ as a tool for establishing sediment chronologies: examples of potentials and limitations of conventional dating models., J. Environ. Radioact., 102, 490-494, doi:10.1016/j.jenvrad.2010.11.010, 2011.

Kucera, M., Weinelt, M. S., Kiefer, T., Pflaumann, U., Hayes.T., Chen, M.-T., Mix, A. C., Barrows, T. T., Cortijo, E., Duprat, J., Juggins, S., and Waelbroeck, C.: Reconstruction of sea-surface temperatures from assemblages of planktonic foraminifera: Multi-technique approach based on geographically constrained calibration data sets and its application to glacial Atlantic and Pacific Oceans, Quaternary Sci. Rev., 24, 951-998, 2005.

L'Abée-Lund, J. H., Eie, J. A., Faugli, P. E., Haugland, S., Hvidsten, N. A., Jensen, A. J., Melvold, K., Pettersen, V., and Saltveit, S. J.: Rivers in Boreal Uplands, in Rivers of Europe, edited by: Tockner, K., Robinson, C. T., and Uehlinger, U., 0-699, Academic Press Elsevier, 2009.

Marret, F. and Zonneveld, K.: Atlas of modern organic-walled dinoflagellate cyst distribution, Rev. Palaeobot. Palynol., 125, 1200, doi:10.1016/S0034-6667(02)00229-4, 2003.

Marret, F., Eirìksson, J., Knudsen, K. L., Turon, J.-L., and Scourse, J. D.: Distribution of dinoflagellate cyst assemblages in surface sediments from the northern and western shelf of Iceland, Rev. Palaeobot. Palynol., 128, 35-53, doi:10.1016/S00346667(03)00111-8, 2004.

Matsuoka, K., Kawami, H., Nagai, S., Iwataki, M., and Takayama, H.: Re-examination of cyst-motile relationships of Polykrikos kofoidii Chatton and Polykrikos schwartzii Bütschli (Gymnodiniales, Dinophyceae), Rev. Palaeobot. Palynol., 154, 79-90, 2009.

Matthiessen, J.: Distribution patterns of dinoflagellate cysts and other organic-walled microfossils in recent NorwegianGreenland Sea sediments, Mar. Micropaleontol., 24, 307-334, doi:10.1016/0377-8398(94)00016-G, 1995.

Maslin, M. A., Shackleton, N. J., and Pflaumann, U.: Surface water temperature, salinity, and density changes in the northeast Atlantic during the last 45,000 years: Heinrich events, deep water formation, and climatic rebounds, Paleoceanography, 10, 527544, doi:10.1029/94PA03040, 1995.

McMinn, A.: Recent dinoflagellate cysts from estuaries on the central coast of New South Wales, Australia, Micropaleontology, 37 , 269-287, 1991.

Milzer, G., Giraudeau, J., Faust, J., Knies, J., Eynau, F., and Rühlemann, C.: Spatial distribution of benthic foraminiferal stable isotopes and dinocyst assemblages in surface sediments of the Trondheimsfjord, central Norway, Biogeosciences, 10, 1-16, doi:10.5194/bg-10-1-2013, 2013.
Nehring, S.: Dinoflagellate resting cysts in recent sediments of tide western Baltic as indicators for the occurrence of "non-indigenous" species in the water column, Institut für Meereskunde, Universität Kiel, in: Proceedings of the 13th Symposium of the Saldo Marine Biologists, Riga 1993: 79-85, 1997 Ed. A AndrugaitaL Institue of Aquatic Ecology, University of Latvia, ISBN 9984-509-90-7, 1997.

Ottersen, G., Planque, B., Belgrano, A., Post, E., Reid, P., and Stenseth, N.: Ecological effects of the North Atlantic Oscillation, Oecologia, 128, 1-14, doi:10.1007/s004420100655, 2001.

Parke, M. and Dixon, P. S.: Revised check-list of British marine algae, J. Mar. Biol. Assoc. UK, 44, 499-542, 1964.

Penaud, A., Eynaud, F., Turon, J. L., Zaragosi, S., Marret, F., and Bourillet, J. F.: Interglacial variability (MIS 5 and MIS 7) and dinoflagellate cyst assemblages in the Bay of Biscay (North Atlantic), Mar. Micropal., 68, 136-155, doi:10.1016/j.marmicro.2008.01.007, 2008.

Pettersson, L.-E.: Totalavløpet fra Norges vassdrag 1900-2010 (Rapport nr 39-2012), Oslo, ISBN: 978-82-410-0827-6, 2012.

Pflaumann, U., Duprat, C., Pujol, C., and Labeyrie, L.: SIMMAX: A modern analog technique to deduce Atlantic sea surface temperatures from planktonic foraminifera in deep-sea sediments, Paleoceanography, 11, 15-35, 1996.

Pospelova, V., de Vernal, A., and Pedersen, T. F.: Distribution of dinoflagellate cysts in surface sediments from the northeastern Pacific Ocean $\left(43-25^{\circ} \mathrm{N}\right)$ in relation to sea-surface temperature, salinity, productivity and coastal upwelling, Mar. Micropaleontol., 68, 21-48, doi:10.1016/j.marmicro.2008.01.008, 2008.

R Development Core Team: R: A language and environment for statistical computing, R Foundati, Vienna, Austria, available at: http://www.r-project.org, 2008.

Radi, T. and de Vernal, A.: Dinocyst distribution in surface sediments from the northeastern Pacific margin $\left(40-60^{\circ} \mathrm{N}\right)$ in relation to hydrographic conditions, productivity and upwelling, Rev. Palaeobot. Palynol., 128, 169-193, doi:10.1016/S00346667(03)00118-0, 2004.

Radi, T. and de Vernal, A.: Dinocysts as proxy of primary productivity in mid-high latitudes of the Northern Hemisphere, Mar. Micropaleontol., 68, 84-114, doi:10.1016/j.marmicro.2008.01.012, 2008.

Riding, J. B. and Kyffin-Hughes, J. E.: A review of the laboratory preparation of palynomorphs with a description of an effective non-acid technique, Rev. Bras. Paleontol., 7, 13-44, 2004.

Robbins, J. A. and Edgington, D. N.: Determination of recent sedimentation rates in Lake Michigan using Pb-210 ad CS-137, Geochim. Cosmochim. Ac., 39, 285-304, 1975.

Rochon, A., de Vernal, A., Turon, J.-L., Matthiessen, J., and Head, M. J.: Distribution of recent dinoflagellate cysts in surface sediments from the North Atlantic Ocean and adjacent seas in relation to sea-surface parameters, Am. Assoc. Stratigr. Palynol., 35, 1-146, doi:10.1016/0377-8398(94)00016-G, 1999.

Sætre, M. M. L., Dale, B., Abdullahb, M. I., and Sætre, G. P.: Dinoflagellate cysts as potential indicators of industrial pollution in a Norwegian fjord, Mar. Environ. Res., 44, 167-189, 1997.

Sætre, R.: Features of the central Norwegian shelf circulation, Cont. Shelf Res., 19, 1809-1831, 1999.

Sætre, R.: Norwegian Coastal Current, edited by R. Sætre, Tapir Academic Press, 2007. 
Sakshaug, E. and Myklestad, S.: Studies on the phytoplankton ecology of the Trondheimsfjord.III Dynamics of phytoplankton blooms in relation to environmental factors, bioassy experiments and parameters for the physiological state of the populations, J. Exp. Mar. Biol. Ecol., 11, 157-188, 1973.

Schmidt, S., Howa, H., Diallo, A., Cremer, M., Duros, P., Fontanier, C., Deflandre, B., Metzger, E., and Mulder, T.: Recent sediment transport and deposition in the Cap-Ferret Canyon, South-East margin of Bay of Biscay, Deep-Sea Res. Part II, doi:10.1016/j.dsr2.2013.06.004, 2013.

Sherman, K. and Hempel, G.: The UNEP Large Marine Ecosystem Report: A perspective on changing conditions in LMEs of the world's Regional Seas, UNEP LME Report, No. 182, 0-872, 2008.

Smayda, T. J. and Reynolds, C. S.: Strategies of marine dinoflagellate survival and some rules of assembly, J. Sea Res., 49, 95-106, doi:10.1016/S1385-1101(02)00219-8, 2003.

Sorrel, P., Popescu, S.-M., Head, M. J., Suc, J. P., Klotz, S., and Oberhänsli, H.: Hydrographic development of the Aral Sea during the last 2000 years based on a quantitative analysis of dinoflagellate cysts, Palaeogeogr. Palaeocl., 234, 304-327, doi:10.1016/j.palaeo.2005.10.012, 2006.

Stockmarr, J.: Tablets with spores used in absolute pollen analysis, Pollen et Spores, 8, 615-621, 1971.

Strømgren, T.: Zooplankton and Hydrography in Trondheimsfjorden on the west coast of Norway, R. Nor. Soc. Sci. Lett. Museum, 51-60, 1-38, doi:10.1016/0024-3841(84)90026-3, 1974.

Tangen, K. and Arff, J.: Høvringen wastewater plant and the environmental quality of the Trondheimfjord (OCN R-23027), Trondheim (Norway), 2003.

Telford, R. J. and Birks, H. J. B.: Effect of uneven sampling along an environmental gradient on transfer-function performance, J. Paleolimnol., 46, 99-106, doi:10.1007/s10933-011-9523-z, 2011.

Van Nieuwenhove, N., Bauch, H., and Matthiessen, J.: Last interglacial surface water conditions in the eastern Nordic Seas inferred from dinocyst and foraminiferal assemblages, Mar. Micropaleontol., 66, 247-263, doi:10.1016/j.marmicro.2007.10.004, 2008.

Vellinga, M. and Wood, R.: Global climatic impacts of a collapse of the Atlantic thermohaline circulation, Clim. Change, 54, 251267, 2002.

Visbeck, M., Chassignet, E., P., Curry, R., Dickson, B., and Krahmann, G.: The Ocean's Response to North Atlantic Oscillation Variability, in: The North Atlantic Oscillation: Climatic Significance and Environmental Impact, edited by: Hurrell, J. W., 11345, Washington D.C., 2003.
Von Detten, P., Faude, O., and Meyer, T.: Leitfaden zur statistischen Auswertung von empirischen Studien, 1-44, 2008.

Waelbroeck, C., Mulitza, S., Spero, H., Dokken, T., Kiefer, T., and Cortijo, E.: A global compilation of late Holocene planktonic foraminiferal $\delta^{18} \mathrm{O}$ : relationship between surface water temperature and $\delta^{18} \mathrm{O}$, Quaternary Sci. Rev., 24, 853-868, doi:10.1016/j.quascirev.2003.10.014, 2005.

Wall, D. and Dale, B.: The resting cysts of modern marine dinoflagellates and their paleontological significance, Rev. Palaeobot. Palynol., 2, 349-354, 1967.

Zaragosi, S., Eynaud, F., Pujol, C., Auffret, G. A., Turon, J.-L., and Garlan, T.: Initiation of the European deglaciation as recorded in the northwestern Bay of Biscay slope environments (Meriadzek Terrace and Trevelyan Escarpment): a multi-proxy approach, Earth Planet. Sci. Lett., 188, 493-507, 2001.

Zonneveld, K. A. F., Versteegh, G. J. M., and de Lange, G. J.: Preservation of organic-walled dinoflagellate cysts in different oxygen regimes: a 10,000 year natural experiment, Mar. Micropaleontol., 29, 393-405, 1997.

Zonneveld, K. A. F., Versteegh, G. J. M., and de Lange, G. J.: Palaeoproductivity and post-depositional aerobic organic matter decay reflected by dinoflagellate cyst assemblages of the Eastern Mediterranean S1 sapropel ABC26, Mar. Geol., 172, 181-195, 2001.

Zonneveld, K. A. F., Versteegh, G., and Kodrans-Nsiah, M.: Preservation and organic chemistry of Late Cenozoic organic-walled dinoflagellate cysts: A review, Mar. Micropaleontol., 68, 179197, doi:10.1016/j.marmicro.2008.01.015, 2008.

Zonneveld, K. A. F., Marret, F., Versteegh, G. J. M., Bogus, K., Bonnet, S., Bouimetarhan, I., Crouch, E., de Vernal, A., Elshanawany, R., Edwards, L., Esper, O., Forke, S., Grøsfjeld, K., Henry, M., Holzwarth, U., Kielt, J.-F., Kim, S.Y., Ladouceur, S., Ledu, D., Chen, L., Limoges, A., Londeix, L., Lu, S.-H., Mahmoud, M. S., Marino, G., Matsouka, K., Matthiessen, J., Mildenhal, D. C., Mudie, P., Neil, H. L., Pospelova, V., Qi, Y., Radi, T., Richerol, T., Rochon, A., Sangiorgi, F., Solignac, S., Turon, J.-L., Verleye, T., Wang, Y., Wang, Z., and Young, M.: Atlas of modern dinoflagellate cyst distribution based on 2405 data points, Rev. Palaeobot. Palyno., 191, 1197, doi:10.1016/j.revpalbo.2012.08.003, 2013. 